\title{
Middle East Respiratory Syndrome (MERS) Virus-Pathophysiological Axis and the Current Treatment Strategies
}

\author{
Abdullah M Alnuqaydan, ${ }^{1}$ Abdulmajeed G Almutary, ${ }^{1}$ Arulmalar Sukamaran, ${ }^{2}$ Brian Tay Wei Yang, ${ }^{2}$ \\ Xiao Ting Lee, ${ }^{2}$ Wei Xuan Lim, ${ }^{2}$ Yee Min $\mathrm{Ng}^{2}{ }^{2}$ Rania Ibrahim, ${ }^{3}$ Thiviya Darmarajan, ${ }^{3}$ \\ Satheeshkumar Nanjappan, ${ }^{4}$ Jestin Chellian, ${ }^{5}$ Mayuren Candasamy, ${ }^{5}$ Thiagarajan Madheswaran, ${ }^{6}$ \\ Ankur Sharma, ${ }^{7}$ Harish Dureja, ${ }^{8}$ Parteek Prasher, ${ }^{9}$ Nitin Verma, ${ }^{10}$ Deepak Kumar, ${ }^{11}$ Kishneth Palaniveloo, ${ }^{12}$ \\ Dheeraj Bisht, ${ }^{13}$ Gaurav Gupta, ${ }^{14}$ Jyotsana R. Madan, ${ }^{15}$ Sachin Kumar Singh, ${ }^{16}$ Niraj Kumar Jha, ${ }^{17}$ \\ Kamal Dua, ${ }^{18,19}$ and Dinesh Kumar Chellappan ${ }^{5,19}$
}

Received 11 February 2021; accepted 19 May 2021; published online 8 June 2021

\begin{abstract}
Middle East respiratory syndrome (MERS) is a lethal respiratory disease with its first case reported back in 2012 (Jeddah, Saudi Arabia). It is a novel, single-stranded, positive-sense RNA beta coronavirus (MERS-CoV) that was isolated from a patient who died from a severe respiratory illness. Later, it was found that this patient was infected with MERS. MERS is endemic to countries in the Middle East regions, such as Saudi Arabia, Jordan, Qatar, Oman, Kuwait and the United Arab Emirates. It has been reported that the MERS virus originated from bats and dromedary camels, the natural hosts of MERS-CoV. The transmission of the virus to humans has been thought to be either direct or indirect. Few camel-to-human transmissions were reported earlier. However, the mode of transmission of how the virus affects humans remains unanswered. Moreover, outbreaks in either familybased or hospital-based settings were observed with high mortality rates, especially in individuals who did not receive proper management or those with underlying comorbidities, such as diabetes and renal failure. Since then, there have been numerous reports hypothesising complications in fatal cases of MERS. Over the years, various diagnostic methods, treatment strategies and preventive measures have been strategised in containing
\end{abstract}

Guest Editor: Claudio Salomon

${ }^{1}$ Department of Medical Biotechnology, College of Applied Medical Sciences, Qassim University, Buraydah, Saudi Arabia.

${ }^{2}$ School of Pharmacy, International Medical University, 126, Jalan Jalil Perkasa 19, Bukit Jalil, 57000, Kuala Lumpur, Malaysia.

${ }^{3}$ School of Health Sciences, International Medical University, 126, Jalan Jalil Perkasa 19, Bukit Jalil, 57000, Kuala Lumpur, Malaysia.

${ }^{4}$ Department of Natural Products, National Institute of Pharmaceutical Education \& Research (NIPER-Kolkata), Chunilal Bhawan, Maniktala, Kolkata, West Bengal 700054, India.

${ }^{5}$ Department of Life Sciences, International Medical University, Bukit Jalil, 57000, Kuala Lumpur, Malaysia.

${ }^{6}$ Department of Pharmaceutical Technology, International Medical University, Bukit Jalil, 57000, Kuala Lumpur, Malaysia.

${ }^{7}$ Department of Life Science, School of Basic Science and Research, Sharda University, Knowledge Park, Uttar Pradesh, 201310, India.

${ }^{8}$ Faculty of Pharmaceutical Sciences, Maharshi Dayanand University, Rohtak, India.

${ }^{9}$ Department of Chemistry, University of Petroleum \& Energy Studies, Energy Acres, Dehradun, 248007, India.

${ }^{10}$ Chitkara University School of Pharmacy, Chitkara University, Atal Shiksha Kunj, Atal Nagar, Himachal Pradesh 174103, India.
${ }^{11}$ School of Pharmaceutical Sciences, Shoolini University, Solan, Himachal Pradesh 173229, India.

${ }^{12}$ Institute of Ocean and Earth Sciences, Institute for Advanced Studies Building, University of Malaya, 50603, Kuala Lumpur, Malaysia.

${ }^{13}$ Department of Pharmaceutical Sciences Bhimtal, Kumaun University Nainital, Uttarakhand, 263136, India.

${ }^{14}$ School of Pharmacy, Suresh Gyan Vihar University, Jaipur, India.

${ }^{15}$ Department of Pharmaceutics, Smt. Kashibai Navale College of Pharmacy, Savitribai Phule Pune University, Pune, Maharashtra, India.

${ }^{16}$ School of Pharmaceutical Sciences, Lovely Professional University, Jalandhar-Delhi G.T Road, Phagwara, Punjab, India.

${ }^{17}$ Department of Biotechnology, School of Engineering \& Technology (SET), Sharda University, Greater Noida, Uttar Pradesh 201310, India.

${ }^{18}$ Discipline of Pharmacy, Graduate School of Health, University of Technology Sydney, Ultimo, NSW 2007, Australia.

${ }^{19}$ To whom correspondence should be addressed. (e-mail: Kamal.Dua@uts.edu.au; Dinesh_Kumar@imu.edu.my) 
the MERS infection. Evidence from multiple sources implicated that no treatment options and vaccines have been developed in specific, for the direct management of MERS-CoV infection. Nevertheless, there are supportive measures outlined in response to symptomrelated management. Health authorities should stress more on infection and prevention control measures, to ensure that MERS remains as a low-level threat to public health.

KEY WORDS: Middle East respiratory syndrome (MERS); endemic; transmission; lower respiratory tract (LRT) diseases; vaccine.

\section{INTRODUCTION}

Middle East respiratory syndrome (MERS) is caused by a type of coronavirus named Middle East respiratory syndrome coronavirus (MERS-CoV) [1]. MERS-CoV is a zoonotic virus that originated from dromedary camels. However, the exact route of transmission to humans remains unknown. As the name implies, this disease is relatively prominent in the Middle East region as compared to other parts of the world. The first case of MERS was reported in the year 2012 at Jeddah, Saudi Arabia, where a man was diagnosed with pneumonia and kidney failure [2]. Soon, MERS had spread to neighbouring countries such as Qatar and Iran, eventually spreading to the rest of the globe [3]. The Republic of South Korea was the first country with the largest outbreak outside of the Middle East region; and had reported its first case in the year 2015, which eventually led to a major outbreak in the region [4]. To date, $>2,400$ cases have been reported globally by the World Health Organization (WHO), including $>850$ deaths (case fatality rate $34.4 \%$ ) [5].

This topical review discusses on several aspects that include the origin of the virus, epidemiology, transmission of MERS-CoV, risk factors, signs and symptoms, pathogenesis, complications, diagnosis of the infection, treatment, public awareness and strategies to prevent MERS-CoV infection.

\section{ORIGIN OF THE MERS CORONAVIRUS}

Although, the accurate origin of this virus is yet to be known, the MERS virus is reported to be transmitted primarily through bats and camels.

\section{Bats}

Since its outbreak in the year 2012, the Middle East respiratory syndrome (MERS) has become a global concern. It was only recently that the causative agent for this severe respiratory disease was identified, which is the MERS-CoV. The questions revolving around the origin of the MERS-CoV still remain unanswered. After several molecular investigations that were conducted in 2013, Ziad et al. reported that bats in Saudi Arabia were infected by several alphacoronaviruses and beta-coronaviruses [6]. It is now known that MERS-CoV is classified as a lineage $\mathrm{C}$ beta-coronavirus. It is found in bats from the Vespertilionidae family, which were known as European Pipistrellus bats [7]. Apart from the Pipistrellus bat coronavirus HKU5 (Pi-BatCoV HKU5) identified in Hong Kong, MERS-CoV was also found to be related to another species of bat-related virus from the same family which is known as Tylonycteris bat coronavirus HKU4 (Ty-BatCoV HKU4) [8]. A study conducted to examine the genetic characterisation of beta-coronavirus lineage $\mathrm{C}$ viruses in bats revealed that the RNA polymerase of Pi-BatCoV HKU5 was more closely related to the MERS-CoV, whereas the spike gene of MERS-CoV was more closely related to TyBatCoV HKU4. Moreover, Pi-BatCoV HKU5 displayed a significant divergence in the spike protein which enabled them to adapt themselves in a host habitat [9]. Evidence provided by Anthony et al. had further strengthened the previous finding that bats are the natural hosts of MERS$\mathrm{CoV}$. Findings of phylogenetic analysis suggested that recombination of S1 subunits of the spike gene causes the variation in spike phenotype which is required for the emergence of MERS-CoV in humans [10]. Interestingly, the detection of cell surface CD26/DPP4 expression in bats further supported the previous findings that bats are the origin point of MERS$\mathrm{CoV}$ [11]. In a separate study conducted to investigate the relationship between human MERS coronavirus and the coronavirus found in bats of South Africa, it was found that $\mathrm{CoVs}$ which were identified in bats from South Africa were even more phylogenetically similar to MERS CoV isolated from humans [7]. Thus, bats were claimed to be the primary reservoir for the Middle East respiratory syndrome coronavirus. The evidence of bats possessing a greater threat to humans as compared to other animals and abilities to unleash human diseases were reported in 2013 [12]. In 2017, a study carried out by Widagdo et al. on the distribution of MERS$\mathrm{CoV}$ tissues in bats found that the receptor DPP4 was preferential to be in the intestinal tract of insectivorous bats. This gave an insight regarding the transmission of MERSlike-CoV that it was mainly via the faecal-oral route [13].

\section{Camels}

In addition to the above, animal studies were also conducted on European hedgehogs from Germany to analyse the presence of beta-coronavirus. The findings suggested that non-bat hosts should not be excluded from the origin of betacoronavirus [14]. Therefore, major livestock species such as camels, goats, sheep and cows in MERS-CoV-affected region like Jordan were also tested for the presence of neutralising antibodies that specifically appeared in MERS-infected animals $[15,16]$. Rhesus macaques was then found to be the potential model for MERS-CoV research [17]. Apart from detection of neutralising antibodies, identification of virus receptors was also used to identify the infected animals and to predict the possible origin. Research had shown that horse and camel receptors possessed more potent MERS-CoV receptor for the entry of virus compared to bats and goat receptors [11]. Nevertheless, comparison between genetic sequences of camel-derived MERS-CoV and human MERS$\mathrm{CoV}$ from Oman and Qatar was done. It was reported that MERS-CoV derived from camel is closely related to human MERS-CoV sequences [18]. Sero-prevalence of MERS was 
also determined in dromedary camels which were from two geographically separated herds in Jordan, Nigeria, Kenya and Laikipia County. The results showed that dromedary camels indicated a high sero-prevalence to MERS-CoV especially the young dromedary camels in Jordan [19-24]. This finding was further supported by a study conducted in Dubai, United Arab Emirates, after the identification of beta-coronaviruses in faecal samples in dromedaries. Infections had been on a rise in dromedary camels of age 2 to 4 years [25, 26].

In 2014, another study was published that supported the evidence of dromedary camels being the only animal species to be the host of MERS-CoV. It also discussed the potential interaction between human and dromedary camels which increased the chance of humans being infected with MERS. Nevertheless, intensified production of dromedary camels and urbanisation encouraged the emergence of MERS-CoV in human population in Arabian peninsula [27]. Surveillance done by Jamal et al. and other researchers in Saudi Arabia in 2014 and 2015 showed that MERS-CoV and human alphacoronavirus co-circulated at high prevalence. The study revealed that the upper respiratory tract is the most commonly affected area in the human body. In 2015, an experimental result showed that dromedary camels shed massive quantities of virus from the upper respiratory tract and serological survey further showed that MERS-CoV antibodies were found to be present in camel-exposed individuals [28]. Therefore, camels are believed to be the reservoir for MERS-CoV. A number of studies suggested that virus was present in dromedary camels several decades ago. Although multiple surveillance and phylogenetic studies suggested that bat was the origin, other studies reported that dromedary camels were the ones causing outbreak of human infections [29].

\section{EPIDEMIOLOGY}

A number of countries were affected due to the spread of the MERS-CoV (Fig. 1).

\section{The Middle East}

In September 2012, the first reported case of MERS$\mathrm{CoV}$ in mankind occurred in Jeddah, Saudi Arabia, where a man died from severe pneumonia [30-32]. Even after numerous outbreaks of MERS-CoV in the following years, in the Middle East region, the issue remained present and relevant especially in Saudi Arabia. Based on World Health Organisation (WHO), data showed that there have been two reported death cases from the period of 16 June to 23 June 2017 among the two active clusters in the region of Riyadh. There have been many reported cases since then that is associated with transmission within healthcare facilities or known as nosocomial outbreak [33, 34]. Close family contact with the infected individuals due to overcrowding in hospital facilities is also identified as a mode of transmission [35, 36]. Other causes of outbreak such as poor control of infectious disease by the hospital and improper quarantine of the infected individual were also identified and reported [37]. Outbreaks have also spread to other parts of the Middle East such as Iran and nearby countries. In Kerman province of Iran, outbreak occurred due to contact with an individual who experienced respiratory infection whilst in Saudi Arabia $[38,39]$. However, subsequent transmission in Iran showed to be patient-patient transmission [40].

\section{Europe}

A second case of MERS-CoV was reported in the UK where a Qatari national received treatment at a local hospital in England. This imported case of MERS-CoV triggered the Public Health England to establish an enhanced surveillance system to identify future possible cases especially among travellers from Middle East [41]. Later, Italy also reported an imported case of MERS from a man who returned from holiday in Jordan. Secondary infections were identified but he recovered soon after [42]. Imported cases of MERS infection were also reported in countries namely, Netherlands and Greece [43].

\section{South Korea}

One of the largest outbreaks of MERS-CoV outside Middle East countries was reported in the Republic of South Korea, which reported its first case of MERS-CoV through a 68-year-old man who was returning to Seoul after a visit to Bahrain, United Arab Emirates, Saudi Arabia and Qatar [4446]. Epidemiological investigations confirmed that the particular individual had visited 4 different hospitals before being diagnosed with MERS-CoV and received treatment in the fifth hospital [47]. Health situation in South Korea went out of control, termed as super spreading events (SSE) where the infection spread rapidly throughout the country with a confirmed 186 cases and 36 deaths. This clearly showed that South Korea was generally not prepared for an emerging infectious disease [48]. With the outbreak, the South Korean government immediately summoned a Rapid Response Team (RRT) to control the situation. They identified a 20/80 rule, where it is predicted that $20 \%$ of any given population are responsible for $80 \%$ of the transmission [49]. The RRT also identified several factors that have contributed to SSE, which includes lack of professional infectious control personnel in healthcare facilities, delayed diagnosis, crowded environment in hospital facilities and unique cultural factors of seeking medical attention in multiple clinics or "doctor shopping" [50-52]. Crowding in hospital facilities as the cause of SSE is also supported by several other researchers whereby the chance of contact for transmission was high [53-55]. The cultural traditions and norms of the Korean culture, where many visitors stayed with patients, had also contributed to SSE as close contact occurred [56]. In addition, the Korean healthcare system also came under fire because of the widespread infections within a brief period as compared to other countries in the Asia Pacific region. It was identified that there was a failure in the national quarantine system to control the spread and outbreak of the disease [57].

\section{South East Asia}

Cases of MERS-CoV infection have also been reported in the South East Asia region, including Malaysia, Thailand and the Philippines. The first reported case in the Philippines, in February 2015, originated from a Saudi Arabian female 


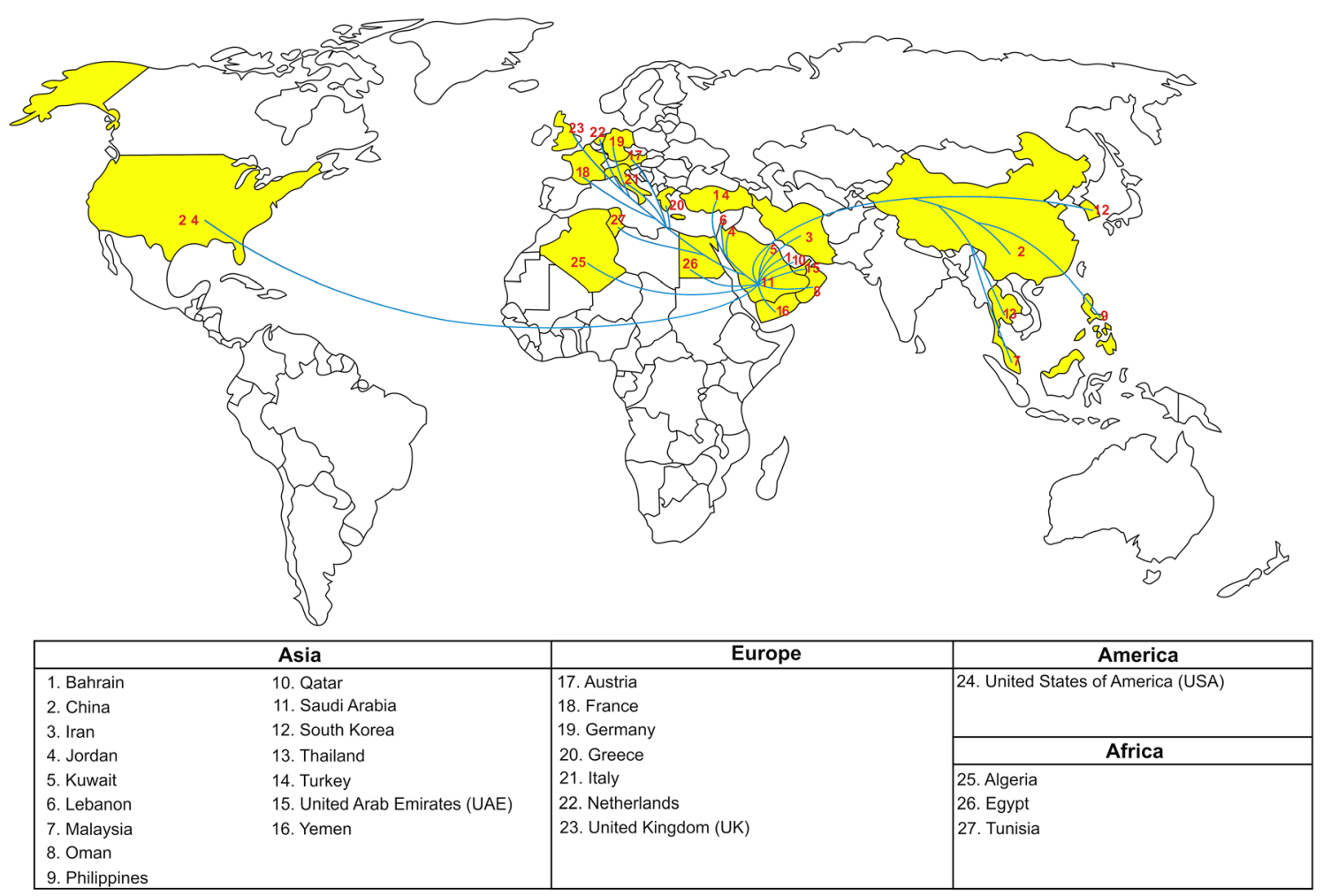

Fig. 1. Geographical distribution of the countries that were affected the most due to the spread of MERS-CoV

who travelled with her husband to Philippines. Efforts had been made to trace the subject's contacts for the duration through which the subject travelled including contact tracing of flights travelled. Among all of them traced, none were tested positive for MERS-CoV, but several developed respiratory symptoms [58]. In the same year, there was also a reported case in Thailand, of a traveller returning from Oman [59].

\section{China}

The first confirmed case in mainland China was a 44year-old male traveller who travelled back to China after visiting his father who was diagnosed with MERS-CoV in South Korea. He flew to Hong Kong before he entered mainland China through Shenzhen and later arrived at Huizhou [60].

\section{The United States of America (USA)}

A case of MERS-CoV was reported in the USA, from the Indiana state, where a traveller returned from Saudi Arabia. Later, a second reported case, which is not related to the first case, followed suit in the state of Florida [61].

\section{TRANSMISSION}

\section{Route of transmission}

A research conducted in 2013 on the stability of MERS$\mathrm{CoV}$ under different environmental conditions showed that MERS-CoV could be transmitted via contact or fomite transmission due to its stability in the environment [62].
Moreover, according to the data from intrinsic disorder analysis, MERS-CoV possesses elevated risk of oral-faecal, oral-urine and saliva transmissibility due to prolong existence in the environment [63]. A small number of sporadic MERS cases that were reported in the early outbreak of MERS-CoV infection indicated that MERS-CoV would not cause rapid human-to-human transmission as compared to SARS infection (Fig. 2). This provided an insight to understand and analyse the transmission dynamics of MERS-CoV [64]. Until now, identification of the mode of transmission was still being the obstacle because it was difficult to trace each case which lasted only for a brief period of time [65].

\section{Zoonotic transmission (animals to humans)}

Transmission of MERS-CoV from animals to humans is rare due to limited evidence. However, infrequent cases from zoonotic transmission occupied greater proportion of the total size of epidemic [66]. Although, there are cases of human infections with MERS-CoV after close contact with animals such as camels, serologic evidence of human infections was not common among animal workers in Southern Saudi Arabia. They were believed to have close contact with camels. This phenomenon partially reflects the rarity of zoonotic transmission [1] [67-69]. However, the ability of camels to transmit the disease cannot be excluded. This is because camel-derived MERS-CoV sequence from Oman and Qatar was found to be closely related to human MERSCoV. Viral shedding was found on nasal and conjunctival swabs from camels. This gave an insight that transmission could occur through respiratory route. Moreover, detection of MERS-CoV RNA in infected camels' milk may increase the chance of transmission in humans through consumption of 


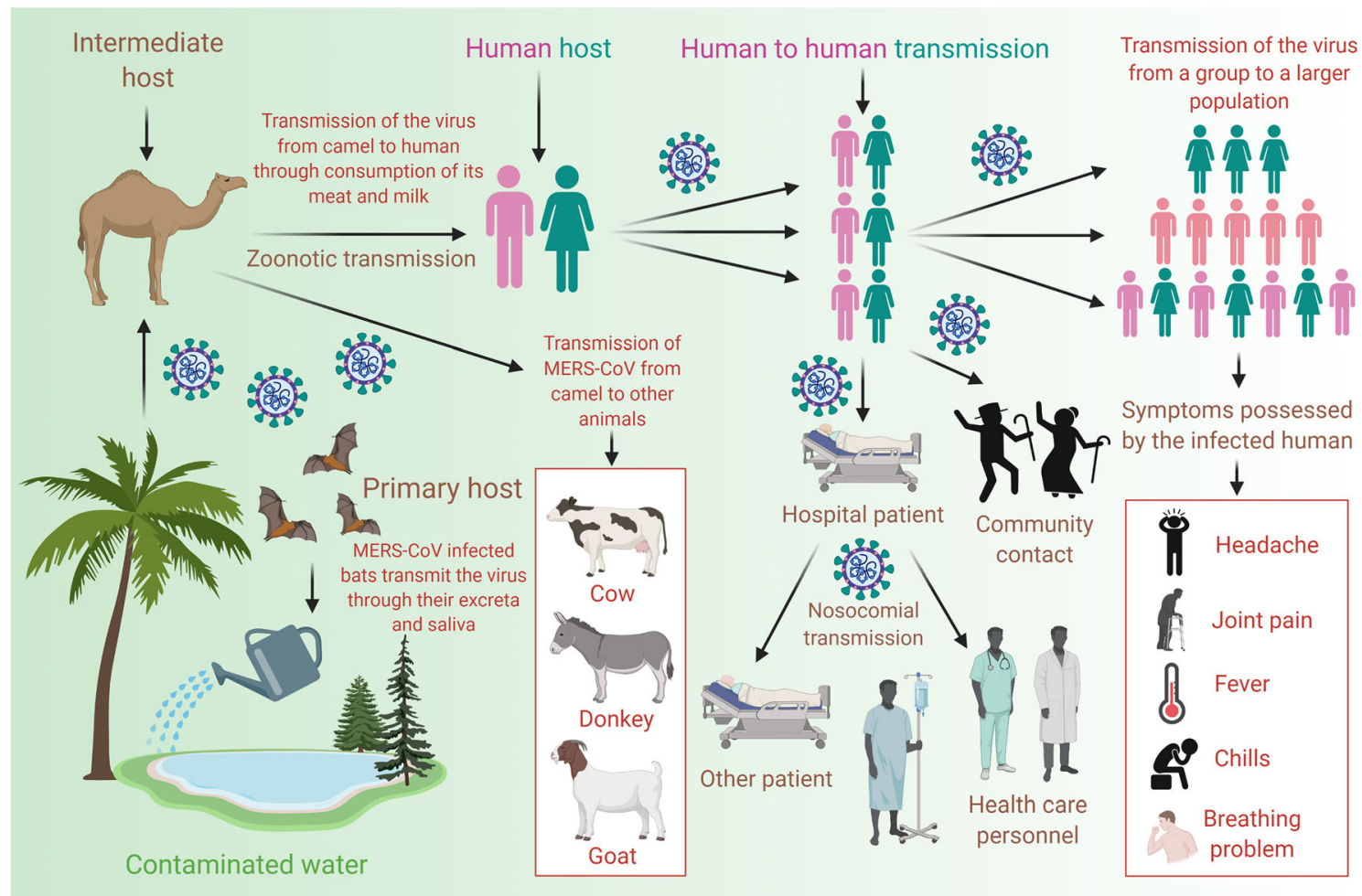

Fig. 2. Schematic depiction of the transmission pattern of MERS-CoV and symptoms possessed by infected individual

milk and uncooked meat [70]. The probability of bat-tohuman transmission was discussed recently and its finding proposed the possibility of a direct transmission or through intermediate hosts [71].

\section{Human to human transmission}

A research conducted in 2013 to estimate virus transmissibility and epidemic potential of MERS-CoV showed that MERS-CoV did not have pandemic potential yet. Data on human-to-human transmission was relatively limited. Results of this study showed that the $R_{0}$ (basic reproductive number) was less than 1 which indicated that virus transmission in 2013 was self-limiting [71]. However, analysis of human clusters proved that, if MERS-CoV infection occurred after implementation of infection control, the transmission was no longer self-limiting [72]. Human-to-human transmission occurred due to two major factors, family and healthcare.

\section{Transmission within family members}

In November 2012, the first close contact or human-tohuman transmission was reported in a family cluster living in urban Riyadh. However, the report suggested that transmission among family members was possible to occur, but the risk was relatively lower [73]. Another study found that a person can carry low levels of MERS-CoV RNA without obvious symptoms. In this case, it was known as a silent infection. MERS-CoV infection had been confirmed by RTPCR assay in those silent and mild infections. In another study, MERS-CoV was reported to be found in upper respiratory tracts of seven household contacts [74]. However, the rate of interfamilial transmission still remained unknown
[75]. Serologic testing of close contacts of patient will be useful in identifying the local transmission rate [73].

\section{Transmission among healthcare workers}

Transmission of MERS-CoV infection due to healthcare factors was retrospectively reported from Jordan, Saudi Arabia, between September 1, 2012, and June 15, 2013, and cases were confirmed by RT-PCR [76, 77]. Transmission rate among exposed health care workers in Jordan was $10 \%$ during the hospital outbreak in 2012 [78]. In addition, 42 cases of hospital-associated MERS-CoV infection have been reported by France, Italy, Tunisia and the UK which were known as evidence of human-to-human transmission of MERS-CoV or nosocomial transmission [79, 80]. On the other hand, continuous transmission within community was rare and no reports were found [14] [32] [52] [71] [81, 82]. Nosocomial transmission had been proved to be the root of secondary infections which may infect, mainly, health care workers [83]. A study by Assiri et al. showed that the impact of human-to-human transmission in healthcare setting was associated with considerable morbidity. Epidemiologic investigation and phylogenetic analyses showed that human-tohuman transmission was the most likely form of transmission during outbreak of MERS-CoV [84]. Lack of infectioncontrol measures, improper usage, inadequate prevention and control practices in hospital are the major cause of transmission in healthcare settings [84, 85]. However, asymptomatic and subclinical cases in health care workers were always underdiagnosed. Some individuals were able to shed virus over a prolonged period of time and remained asymptomatic. Therefore, healthcare workers were likely to spread the virus to patients who may cause new infections 
[86]. Hence, hospital transmission was known to be the most profound cause of virus infection which affected mainly nonhealthcare workers [87]. This statement reflects the importance of high awareness to initiate infection control measures and the need to develop specific diagnostic tests to identify MERS-CoV infection [88].

Incidentally, the outbreak in the Republic of Korea was the largest, where the most confirmed cases were associated with nosocomial transmission. The first case of MERS infection in Korea was diagnosed in a 35-year-old man working at a police station in Pyeongtaek, Gyeonggi-do; but the mode of transmission was reported to be indefinite [57]. Ever since, there were 186 patients confirmed to suffer from MERS infections. The infections were transmitted among patients in the same ward and also from one hospital to another. There were 17 hospitals involved in hospital-hospital transmissions. Therefore, MERS-CoV infection in Korea was predominantly affecting the healthcare settings. Numerical analysis conducted in the Republic of Korea indicated the lack of self-protection awareness and targeted control measures, which were the reasons of the outrageous spreading or outbreak of MERS-CoV infection in Korea [89-91].

\section{RISK FACTORS}

\section{Gender}

The outbreak of MERS-CoV in all regions showed that different genders have different risks in being infected by the virus. Male gender has higher incidence rate of infection as compared to the female gender in most outbreaks [92-94]. Predominance of male gender in the Arab peninsula can be linked with its culture and customs that made males having more exposure to camels as compared to females [95]. However, it is in opposite gender ratio among the healthcare workers in South Korea. It is reported that female gender has a higher rate of infection than male gender, as females dominate in healthcare settings [95, 96].

\section{Age}

Jansen et al. concluded that the average age in reported infections during the South Korea outbreak was 55 and 57 years among males and females respectively [96]. In addition, older age individuals were associated with higher mortality rate [97-99]. It was identified that individuals who were aged 65 years old and above have 8 to 9 times higher mortality rate than others [100]. Although MERS-CoV infection is mainly an adult disease, there are also reported cases of infected infants and children [101, 102]. Infected children have lower mortality rate as compared to adults except for infected children with underlying co-morbidities [103].

\section{Underlying medical conditions}

Several case studies have identified that individuals that have co-morbidities is shown to have significantly higher chances of getting infection by MERS-CoV [89]. These comorbidities include diabetes mellitus, heart disease, lung disease, kidney disease, hypertension, cancer and immunosuppressed individuals [36]. The presence of co-morbidities is expressed to have increased the fatality rate by 7-8 times [104]. In addition, smoking has also been highly associated with MERS-CoV infection.

\section{Number of contacts}

The risk of being infected with MERS-CoV is also closely associated with the number of contacts with virus [104-106]. Occupation plays an important role in understanding the spread of disease. Researchers in Qatar have explained that individuals who work closely with dromedary camels, such as individuals that work in slaughter houses, farms and even veterinarians are found to be at higher risk of being infecting with the disease [101]. Family members and relatives of the mentioned occupation have indirect virus exposure as they are living under the same roof [20]. Even healthcare workers are also not spared from risk. There are reported cases where healthcare workers were infected after direct exposure with infected patients. Also, the exposure of contaminated equipment without proper barrier control risks healthcare workers being infected [106].

\section{SIGNS AND SYMPTOMS}

At the beginning of the MERS infection (14 days), the infected patients suffered from myalgia, headache, fever, diarrhoea and vomiting [106-108]. Gastrointestinal symptoms such as diarrhoea, nausea and vomiting were also presented in some patients [77] [108]. Clinical manifestation of MERSCoV ranged from mild upper respiratory symptoms such as cough and shortness of breath to pneumonitis and pneumonia with rapid progression which then lead to acute respiratory distress syndrome and hypoxic lung injury [12] [109]. It was found that it could also cause immunosuppression in patients which led to multi-organ failure such as renal injury [110].

Inflammation of the liver was seen in some patients who were critically ill with increased levels of alanine aminotransferase and aspartate aminotransferase [57] [104]. Thrombocytopenia and lymphopenia were also present in some patients with MERS-CoV infection [110].

A study carried out in South Korea during the MERS outbreak in the year 2015 showed that transmission of MERS-CoV is associated with delay in isolation, high fever and high extensive of chest infiltrates of the patients. Hence, a strict quarantine is the most important action to control the early stage MERS outbreak [111] [89].

\section{PATHOPHYSIOLOGY}

\section{Virus entry into host cells}

The attachment or fusion of MERS-CoV to host cells to initiate infection required two main components, mainly the dipeptidyl peptidase DPP4 (also known as CD 26) that was identified as the host cell receptor for MERS-CoV [111-114]. DPP4 is only expressed in certain species of animals which is responsible for the restriction of species tropism of MERSCoV [115]. Research shows that DPP4 was found in human parenchyma cells of liver, intestines and kidney tissues. It is also found on T and B cells [116]. Animal studies conducted previously proved that transgenic mice with hCD26/DPP4 
receptors were infected with MERS-CoV and exhibited severe respiratory injury and extrapulmonary organ damage [116-119]. This showed that DPP4 is essential for MERS-CoV to infect the species. MERS antigens are found in type I, type II pneumocytes, ciliated bronchial epithelium, unciliated terminal bronchioles and alveolar macrophages [120-123], where the DPP4 receptors are localised.

In addition, the spike glycoprotein (S) (Fig. 3), a crownlike peplomer found on the surface of the enveloped coronavirus particle functions as an entry protein which bounds to cell surface receptor DPP4 on host cells [124]. It is known to mediate virus entry and elicit neutralising antibodies from the host [125]. The $\mathrm{S}$ protein is a type I membrane glycoprotein which consists of two terminals, $\mathrm{N}$ terminal ( $\mathrm{S} 1$ residues) and $\mathrm{C}$-terminal ( $\mathrm{S} 2$ residues). $\mathrm{S} 1$ subunit contains receptor-binding domain (RBD) whereas S2 subunit contains fusion peptide, and heptad repeats 1 and 2 (HR1 and HR2) [100] [126, 127]. The junction of S1 and S2 requires a cleavage done by protease which will activate the fusion of $\mathrm{S}$ protein with the host cells receptors through a lock-and-key interaction enabling the entry of virus. RBD in $\mathrm{S} 1$ subunit will bind to the cellular receptor and trigger the conformation changes in S2 subunit. A six-helix bundle fusion core is formed between heptad repeats 1 and 2 (HR1 and HR2) which facilitates the virus entry into the body [127129]. Another study shows that cleavage also happens at S2 position by a ubiquitously expressed protease known as furin [129]. RBD, HR1 and HR2 binds together and form the stalk region of $\mathrm{S}$ protein which allows fusion of virus with host cells. Therefore, even minor mutations on the $\mathrm{S}$ protein or DPP4 receptor residues can terminate the infection or decrease the fusion of virus to cells [107].

Mutation in the receptor-binding domain (RBD) of viral spike (S) protein of MERS-CoV was observed in South Korean patients $[129,130]$. MERS-CoV enter human cells via two pathways, endosomal membrane fusion and endocytosis. Endosomal membrane fusion involves the cleavage of MERS-CoV spike protein as mentioned in the texts, whereas viruses enter by endocytosis in a cathepsin L-dependent manner when S protein is uncleaved [47]. Subsequently, the viral genomic RNA is released into the host cytoplasm.

\section{Binding of the virus to the host receptor}

MERS-CoV consists of several structural and accessory proteins namely protein M, ORF $4 \mathrm{~b}$ and ORF 5. Studies have shown that these are potent interferon antagonists. Among all, ORF4a protein being the most potent suppresses IFN antiviral activity or IFN production [131]. In another study, Yang et al. had indicated that MERS-CoV ORF4b causes interferon antagonism [132, 133]. Production of antiviral proinflammatory cytokines is the first-line defence in humans. Ex vivo study of human lung cell lines shows that the induction of cytokines was suppressed during MERS-CoV infection [133]. Nevertheless, another study on respiratory epithelial cell line Calu-3 cells demonstrated that there was a delay in the induction or activation of proinflammatory cytokines such as IL-1 $\beta$, IL-8 and IL-6 [134]. Expression of antiviral cytokines such as IFN- $\alpha$ and IFN- $\beta$ was not triggered by viruses in the body [121]. This could be due to the presence of papain-like proteases (PLpro) in the MERSCoV. The PLpro acts as an IFN antagonist, where its domains were shown to block the upregulation of cytokines and had the potential to alter innate immune response against viral infection in the host. Hence, PLpro possessed deubiquitinating and delSGylating activities. It suppressed the production of IFN- $\beta$ by interfering the phosphorylation and nuclear translocation of IFN regulatory factor 3 (IRF3) as well as the innate immune response $[135,136]$.

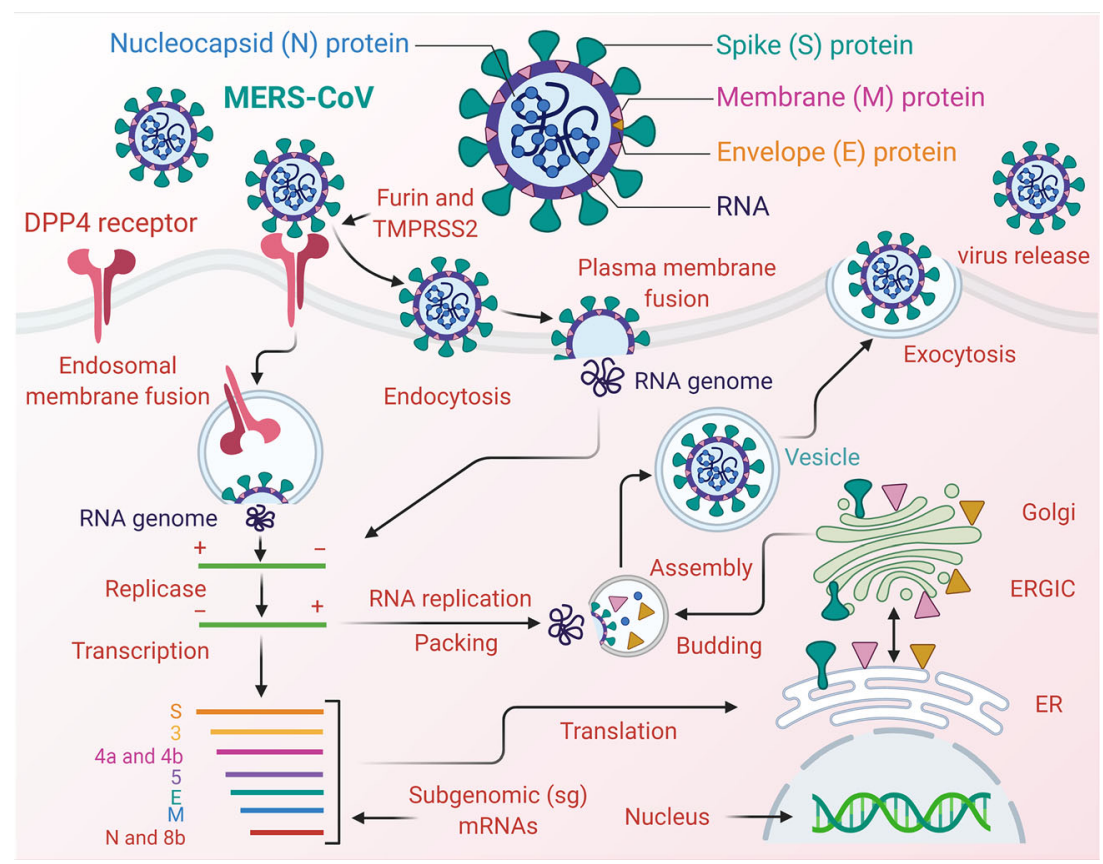

Fig. 3. Schematic illustration of the genomic structure and the life cycle of the MERS-CoV 
Table I. Common Complications Observed in Individuals Who Are Infected by MERS-CoV

\begin{tabular}{|c|c|}
\hline Complications & Description \\
\hline Renal impairment & $\begin{array}{l}\text { Early detection and treatment might be beneficial in preventing } \\
\text { severe renal complications }[144,145] \text {. As such, serum creatinine, } \\
\text { estimated glomerular filtration rate (eGFR) and urine dipstick test } \\
\text { were used as the diagnostic tool to measure kidney function in } \\
\text { patients infected with MERS-CoV. According to research done } \\
\text { in South Korea, the average serum creatinine of an infection } \\
\text { patient is reported to be } 1.51 \pm 2.811 \mathrm{mg} / \mathrm{dL} \text {, higher than the optimal } \\
\text { range, whilst the average eGFR among the patients is } 65.4 \pm 37.82 \mathrm{~mL} / \mathrm{min} / 1.73 \mathrm{~m}^{2} \\
\text { which indicates mild kidney damage. Majority of the patient also showed positive } \\
\text { albumin and blood in urine dipstick test [145]. }\end{array}$ \\
\hline Pregnancy & $\begin{array}{l}\text { There are reported cases of mortality in MERS-CoV-infected pregnant mother or both } \\
\text { pregnant mother and infant and even stillbirth [146-149]. Thirteen case reports in pregnant } \\
\text { women, of which } 2 \text { were asymptomatic, identified } \\
\text { as part of a contact investigation; } 3 \text { patients }(23 \%) \text { died. Two pregnancies ended in foetal } \\
\text { demise and } 2 \text { were born pre-term. No evidence of in utero transmission was seen in severe } \\
\text { acute respiratory syndrome or Middle East respiratory syndrome [150]. Malik et al. reported } \\
\text { a fatal case of both pregnant mother and the infant even after ribavirin-peginterferon- } \alpha \\
\text { combination therapy was administered [147]. However, there are also cases where both infant } \\
\text { and infected pregnant mother survived and recovered from the infection [149]. The } \\
\text { exact cause of death remains a myth. }\end{array}$ \\
\hline $\begin{array}{l}\text { Lung disease } \\
\text { (animal studies) }\end{array}$ & $\begin{array}{l}\text { In an effort to understand MERS-CoV more, several animal models were created such as } \\
\text { the human DPP4 (hDPP4) knockin mice and rhesus macaque model. The findings reported } \\
\text { that MERS-CoV causes lung disease in hDPP4 knocking mice and it appeared to be lethal [151]. } \\
\text { In a similar matter, this strain of coronavirus also caused lower respiratory infection in rhesus macaques [152]. } \\
\text { Similar to humans, renal failure can be seen among infected mice [152]. }\end{array}$ \\
\hline
\end{tabular}

Replication of MERS-CoV was found in human macrophages and monocyte-derived dendritic cells (mDCs) [137139]. Upon infection of MERS-CoV on macrophage and mDCs, viral antigen expression and viral RNA increases. This results in an increase in the IFN- $\lambda 1$, CXCL10 and MxA mRNAs in both macrophages and dendritic cells [139]. Moreover, another in vitro study had reported an increase of titter in the culture media of infected cells and large amounts of type I and III IFNs were induced exclusively in human plasmacytoid dendritic cells (pDCs) [140]. Furthermore, T cells were identified to express DPP4 receptors which make it susceptible as a target of MERS-CoV [141]. In vitro studies show that infection of MERS-CoV on $\mathrm{T}$ cells (both $\mathrm{CD}^{+}$and $\mathrm{CD}^{+}$) in the host induced apoptosis in T cells via intrinsic and extrinsic pathways [139]. These caused viral replication in the host cells that becomes more robust. Animal studies were also conducted on mouse models or mice transduced with Ad/hDPP4 to simulate and analyse host response to MERS-CoV infection. Results indicated that depletion of CD8+ $\mathrm{T}$ cells compromised lung function and depletion of macrophages aggravated virus activity in host cells [142]. Apart from that, another mice model showed type $\mathrm{I}$ interferon response, $\mathrm{CD} 8^{+} \mathrm{T}$ cells and neutralising antibodies which were essential for fighting MERS-CoV in the host [143].

\section{COMPLICATIONS}

Since the emergence of MERS-CoV in the year 2012, several complications are reported (as shown in Table I) in infected patients. These range from renal impairment, multiple organ failure and might even lead to death [144, 153].

\section{DIAGNOSIS}

Real-time RT-PCR assay was a type of commercial test that is widely used [154] to screen MERS infection in patient samples. More widespread mobility is needed for a rapid point-of-care test for the purpose of detecting the virus directly from patient material [75] [155, 156]. People who had been infected with MERS-CoV will have a positive result in RT-PCR [157]. Delayed diagnosis can cause the largest outbreak MERS infection [100].

Real-time reverse transcription-polymerase chain reaction (rRT-PCR) [158, 159] assays were used to target the nucleocapsid $(\mathrm{N})$ gene or $\mathrm{RdRp}$ and amplified product sequence [159] in MERS-CoV. These assays were evaluated with a previously published assay, targeting the region of upstream in the MERS-CoV envelope gene (upE) to detect and confirm the MERS infection in the patients. These rRTPCR assays are rapid, specific, sensitive and reliable and are simple tools that can be used in the emergency diagnostic test for MERS-CoV which are authorised by the US Food and Drug Administration [160-163]. Furthermore, the open reading frame (ORF) 1b assay and ORF1a assay are confirmed in the detection of MERS-CoV. However, the sensitivity of ORF1a assay is slightly lower than upE assay [159]. The ORF1b assay was more specific, but less sensitive, as compared to the ORF1a assay [164]. The results showed that [165] a high sensitivity can be obtained from the 
combination of upE assay and ORF1a assay (RealStar® MERS-CoV RT-PCR diagnostic kit) for rapid detection of MERS-CoV [159] [166].

Wahed et al. described a reverse transcription isothermal recombinase polymerase amplification (RT-RPA) assay to identify MERS infection. The assay employs a partial nucleocapsid gene RNA molecular standard of the MERS$\mathrm{CoV}$. The findings from the study revealed that isothermal RT-RPA could be used for acute patients [167].

An alternative RT-LAMP, known as one-pot reverse transcription loop-mediated isothermal amplification (one-pot RT-LAMP), demonstrated high specificity and sensitivity to detect MERS-CoV. One-pot RT-LAMP can also be used as a diagnostic test during an emergency because of its rapidity and selectivity [154]. Specimens from sputum, nasopharyngeal or oropharyngeal may be screened by upE and ORF1a target genes with the help of rRT-PRCR for the identification of the MERS virus [168].

Presence of MERS-CoV neutralising antibodies in serum and plasma samples collected from patients by using a lentiviral system can be used to determine the virus over the course of the disease [168, 169]. However, this system failed because none of the neutralising activity was observed in the samples tested [170]. The intensity and timing in respiratory viral shedding in MERS infected patients were closely matched with those patients having an acute respiratory syndrome [171]. Another study had highlighted that pseudo particle neutralisation ( $\mathrm{ppNT}$ ) or different types of neutralisations had the effectiveness in sero-epidemiology and diagnosis of MERS-CoV [172].

Serological testing for retrospective diagnosis is only available at the CDC in the USA [172]. This can be used to detect the virus in a close contact of the patient such as healthcare personnel $[173,174]$. Park et al. had conducted a study showing that MERS-CoV S1 IgG ELISA tests and virus neutralisation can be used in the investigation of serologic responses to MERS-CoV. The results showed that most patients developed robust antibody responses in the third week of the disease [174].

Moreover, modification of Identify-Isolate-Inform (3I) tool can detect the risk for MERS infection rapidly in the emergency department patients. The modification included epidemiologic risk factor assessment, travel to the MERS infected countries or contact with infected patients within 14 days, and patients with fewer symptoms like respiratory illness and fever. If the criteria above are met, patients are required to be placed in airborne infection isolation [64].

\section{PREVENTION, CONTROL, TREATMENT AND MANAGEMENT OF THE VIRAL INFECTION}

Rapid advancements of effective therapeutic alternatives are a high priority since no antivirals or vaccines have been approved so far for the treatment of coronaviral diseases. Management of MERS is mainly done by supportive therapy, which includes hydration, antipyretic, analgesics, respiratory therapy and antibiotics if necessary, for bacterial superinfection.

At present, no particular anti-MERS-CoV treatments are available that might be suitable for use in humans. Clinical management of MERS at present is focused on symptoms, offering supportive care along with management of fever and pain, supporting the functioning of vital organs, and treatment of secondary or concurrent bacterial infections $[175,176]$. Cases of MERS, which are mild, are manageable at home. Development of pneumonia can be attributed to predictive factors like high fever, C-reactive protein greater than or equal to $2 \mathrm{mg} / \mathrm{dL}$, older age ( $>56$ years), lymphopenia, high viral load in sputum (threshold cycle value of rRTPCR <28.5) [10] [70] and thrombocytopenia. Acute injury to kidneys (with proteinuria and haematuria) and respiratory failure are found commonly in patients who require hospitalisation due to the severity of the condition and those who need extracorporeal membrane oxygenation, mechanical ventilation and dialyses [175-177].

In different patient states, several empirical treatments have been suggested. In the case of patients who are seriously unwell with MERS, therapies used comprise of corticosteroids, protease inhibitors, convalescent plasma, antiviral agents (e.g. interferons and ribavirin) or a blend of members of these groups. A systematic review was conducted on 30 published studies involving various therapeutic agents that have been used for the treatment of MERS during different outbreaks. The findings suggested the absence of any correct evidence base and reiterated the requirement for conducting controlled trials [178].

\section{Vaccine}

Vaccine development to treat MERS has been under development for several years now since its emergence in 2012. Numerous studies were done to develop a suitable vaccine from variable sources, such as proteins, antibodies and viruses. In an earlier study, the target for vaccine development was identified as the receptor binding domain in the spike (S) protein of MERS coronavirus [179, 180]. Moreover, this S protein-modified vaccine efficiently induced virus-neutralising antibodies along with its genetic stability and growth characteristics which makes it suitable as a vaccine candidate [180]. In the year 2013, Almazan et al. stated that it is possible to use propagation-defective, replication-competent MERS coronavirus as a vaccine candidate [181]. Besides that, in the same year, a separate study was conducted to track the rapid response to emerging coronaviruses by evaluating the serologic and antigenic relationship between MERS coronavirus and other coronaviruses in vaccine forms [182]. However, the question now is, are all these vaccines commercially feasible [183]? In this current era, vaccine development is also done via animal studies where MERS-CoV S protein encoded by two recombinant adenoviral vectors were inserted into the $\mathrm{BALB} / \mathrm{c}$ mice which resulted in increased antibodies. Thus, it is proved that adenoviral-based vaccine can be helpful in reducing MERS transmission [184, 185]. Kupferschmidt, in his study, stated that camel vaccines can be a potential target to curb the $\mathrm{CoV}$ transmission. However, it is not clear whether the vaccine could provide protection on a longterm basis [186]. MERS-CoV spike (S) protein and its receptor-binding domain (RBD)-developed vaccine are considered both safe and effective [143]. In a study conducted on animals, Wang et al. analysed the efficacy of vaccine that were made up of chimeric virus-like particles (VLP) that expressed 
the receptor-binding domain (RBD) of MERS-CoV. It was then concluded that VLP vaccine could be a potential target for the prevention of MERS [187]. Recently, in 2016, Tai et al. constructed five designs and developed RBD subunit vaccines based on different MERS-CoV strains isolated from humans and camels from 2012 through 2015 (2012-RBD, 2013-RBD, 2014-RBD, 2015-RBD and Camel-RBD) and evaluated their ability to neutralise various MERS-CoV strains and MAb escape mutants. It was found that RBD-based MERS vaccines will be able to induce sufficient cross-neutralising antibodies for protection against current circulating strains, as well as other strains that might occur in the future [188].

\section{Advances in vaccine development}

Advances in clinical trial designs, vaccine platforms, technology and bioinformatics are helping with the development of a vaccine for MERS-CoV. Target product profiles for MERS-CoV vaccines from WHO requires three types of vaccines to be developed: a human vaccine for reactive use during outbreaks; a human vaccine for long-term protection of high exposure individuals like healthcare workers and those working with potentially infected camels, and for the prevention of zoonotic transmission like a dromedary camel vaccine [189]. Development is going on for various types of vaccine candidates, including viral vectored vaccines, inactivated whole virus, live attenuated virus, inactivated subunit vaccines and DNA vaccines [190]. A large number of such vaccines use the $\mathrm{S}$ protein, or the domain of $\mathrm{S}$ protein needed for binding to host DPP4 as an immunogen, as neutralising antibodies are primarily driven towards the receptor-binding domain.

\section{Antiviral agents}

Along with ribavirin, mycophenolic acid, interferons and cyclosporine, the repressing effects have been showcased by various other agents too against MERS-CoV in cell cultures. Empirical pegylated interferon alfa-2a, lopinavir-ritonavir and ribavirin have been used in severe cases, though the data for their efficacy is not yet available. In Saudi Arabia (the MIRACLE trial; NCT02845843), there is a random clinical trial going on wherein the comparison of recombinant interferon beta, lopinavir-ritonavir and standard supportive care in MERS patients are being studied. This placebocontrolled, recursive, multicentre, double-blind, randomised controlled trial has been designed to incorporate two distinct components that further comprise two stages. The primary two-stage component has been created for determining futility stopping and for adjusting the sample size but not for efficacy stopping. The second two-stage component has been created for ascertaining efficacy stopping and probable adjustment of the sample size [177].

Newer potent antiviral agents are constantly being investigated and researched as a therapeutic option for MERS-CoV. The current international recommendation as of year 2013 does not suggest anything in particular, however, suggesting that the agents used during the SARS outbreak might be active against MERS-CoV [191]. In a few other studies, researchers in trial experiments concluded that interferon- $\beta 1 b$ with mycophenolic acid could be considered a potential option in the treatment trials of MERS [101] [192]. In a separate trial experiment, it was reported that interferon$\alpha 2 b$ and ribavirin was found to treat and improve the MERSCoV-infected rhesus macaques [193]. In two separate cases of MERS infection, ribavirin and interferon- $\alpha 2 b$ used were studied as the primary and preventive treatment [194]. De Wilde et al., in their research, identified cyclosporine A as an inhibitor of MERS-CoV replication by using MERS CoV, characteristic of rapid replication of the viral RNS synthesis to develop an assay for antiviral compound screening in 96well format. A study reported that alpha interferon (IFN- $\alpha$ ) treatment was found to be 50-fold more sensitive to SARSCoV [195]. A preclinical data collected from an animal study showed IFN-a2b and ribavirin reduces virus replication and improves clinical outcome of MERS-CoV-infected rhesus macaques, and suggested a transcriptomic basis for therapeutic efficacy [196, 197]. In addition, in 2014, researchers found ERK/MAPK and PI3K/AKT/mTOR signalling modulation as the potential antiviral agent for MERS coronavirus infection as identified by temporal kinome analysis [198]. Sharif-Yakan and Kanj have concluded that cyclosporine A, interferonbeta, mycophenolic corrosive, homoharringtonine, anisomycin, cycloheximide and emetine dihydrochloride hydrate to have the strongest in vitro activity against MERSCoV. Dyall et al., in their study, found a total of 27 compounds which belonged to 13 different classes that could act on the MERS-CoV and SARS-CoV. These include oestrogen receptor inhibitors that are usually used for cancer treatment and dopamine receptor inhibitors that are used as antipsychotics [199]. Besides that, after screening of an FDAapproved compound library, four small-molecule MERS-CoV replication inhibitors were identified [200]. Similarly, discovery of structure-based MERS-CoV fusion inhibitor, the HR2P and its analogues by Lu et al. could be further developed into effective viral fusion inhibitors to treat MERS-CoV infection [201, 202]. Adenosine deaminase (ADA), a DPP4 binding protein, competed for dipeptidyl peptidase 4-mediated entry of the MERS-CoV and could be potentially used as an example to develop other antagonists [203]. In an observational study, it was concluded that ribavirin and interferon may be less beneficial to patients with various other comorbidities along with MERS infection. Hence, the search for novel effective antiviral therapies are at large [204]. Adedeji et al. identified broad spectrum inhibitors such as SSYA10-001, which could be used to target multiple coronaviruses [205]. Recently, in 2016, Kim et al. suggested a combination therapy with lopinavir/ritonavir, ribavirin and interferon- $\alpha$ for MERS infection. This was based on a case report of a patient with MERS-CoV infection [206]. In a retrospective study conducted by Shalhoub et al., a combination therapy of IFN- $\alpha 2$ a or IFN- $\beta 1$ a with ribavirin to treat Middle East respiratory syndrome coronavirus pneumonia was studied [207]. Lastly, in the year 2015, a guideline suggestion was researched and published regarding the antiviral treatment for MERS by reflecting the latest evidences [208].

\section{Convalescent plasma}

Clinical trial evaluation is required in MERS patients who have fully recovered (convalescent plasma) for plasma 
use. The therapeutic potential was suggested by pre-clinical animal data wherein the transfer of serum samples from camels immune to MERS-CoV into infected mice resulted in reduced lung histopathology and weight loss [106]. During the Korean outbreak in 2015, out of 13 patients with MERS with respiratory failure, 3 were administered four infusions of convalescent plasma [209]. Neutralising activities were exhibited in two of the three patients. After convalescent plasma infusion, a meaningful serological response was exhibited in the donor plasma with a titre of 1/80 in the plaque reduction neutralisation test (PRNT), but when the PRNT titre was $1 / 40$, such a response was not exhibited. Hence, it was concluded by the authors that for an efficient convalescent plasma infusion in patients with MERS, only such donor plasma must be used wherein the neutralisation activity of PRNT titre is either greater than or equal to $1 / 80$.

\section{Antibiotic therapy}

Generally, patients who are severely ill are subjected to antibiotic therapy empirically. When a retrospective study comprising 136 MERS patients was analysed, it was found that there was no reduction in the mortality through the use of macrolide therapy or quicker clearance of MERS-CoV RNA in comparison to those patients who were not administered macrolide treatment [210].

\section{Systemic corticosteroids}

As per studies, no benefits have been reported from the usage of systemic corticosteroids. Viral clearance was shown to be delayed by systemic corticosteroids in patients who were critically ill and were suffering from MERS-CoV infection [211].

\section{Human monoclonal antibodies}

Regardless of efforts done to develop MERS-CoV vaccine, the prevalence of this pathogen is comparatively low, making it hard to target the population for immunisation. On the other hand, mAbs can be administered in the setting of an outbreak without the need to segregate who may be at most serious risk for contamination. In this type of treatment, available human neutralising $\mathrm{Ab}$ [212] pressure is considered the main incentive in MERS-CoV adaptive development [208] [213]. Ohnuma et al., in their study, found that MERS coronavirus infection can be inhibited by anti-CD26 monoclonal antibody [214]. Sharif-Yakan and Kanj, in their research, mentioned that monoclonal antibodies could be used as a first-line treatment for MERS infection. Similarly, three types of monoclonal antibodies (m336, m337 and m338) were identified by Ying et al., to target the receptor (CD26/DPP4)-binding domain (RBD) of the MERS-CoV spike glycoprotein, which works exceptionally well in neutralising MERS CoV [215, 216]. A conformationdependent neutralising monoclonal antibody specifically targeting receptor-binding domain in MERS-CoV spike protein was also generated [217]. Chen et al., in their research, also found the neutralising monoclonal antibodies specifically targeting the N-terminal domain of the residual region of the MERS-CoV spike protein [218]. In 2013, Song et al. built a recombinant Modified Vaccine virus Ankara (MVA) which expresses the full-length MERS-CoV spike (S) protein (MVA-MERS-S) [191] [219-221]. In a study conducted by Doremalen and his team, reduction of symptoms of MERS in common marmosets was observed after antibodybased therapies against MERS-CoV [222]. Besides, $3.0 \AA$ resolution crystal structure of MERS-CoV RBD bound to the extracellular domain of human DPP4 in the structure of MERS-CoV spike receptor-binding domain complexed with human receptor DPP4 was identified [223, 224]. In 2013, Bosch et al. studied and published the complex structure of the viral receptor-binding domain alongside the host CD26/ dipeptidyl peptidase 4 receptor [225]. Furthermore, it was also found that RBD is also recognised as a great entry inhibitor of MERS-CoV. Other studies have identified proteins as the provider for the better finding of the receptor-binding domain crystal structure [226].

\section{Other treatments}

In a recent study conducted in 2016, Keil et al. found a new method to inactivate MERS-CoV in plasma products by using ultraviolet light and riboflavin-based photochemical treatment. It was then concluded that both these methods were effective in minimising the amount of MERS-CoV below the detection limit in plasma products, thus minimising the risk of transfusion transmission of MERS-CoV [227].

Various types of probable treatments are either being considered, developed or evaluated. A phase 1, first-inhuman, randomised, single-site, double-blind, placebocontrolled study to estimate the tolerability, safety, pharmacokinetics and immunogenicity of single ascending doses of co-administered monoclonal antibodies REGN3048 and REGN3051 administered intravenously in healthy adult volunteers (NCT03301090) is ongoing. The duration of the study will be around 16 months. There is another study wherein those patients who were administered with extracorporeal membrane oxygenation (ECMO) support were compared with those who did not receive ECMO support (NCT02627378). Various polyclonal and monoclonal neutralising antibody products, including human heavy-chain antibodies, offer protection in animal models; however, controlled trials are still required for pre-exposure or postexposure prophylaxis in outbreak management [228-230].

\section{PUBLIC AWARENESS}

\section{Saudi Arabia}

Understanding the threats of this syndrome, numerous studies regarding the degree of awareness among people around the world were conducted. Public knowledge regarding MERS outbreak varies depending on the outbreak region. At first, when it originated from the Arabian Peninsula, many were not aware of it. However, as time went, people became more aware of the MERS. In the year 2013, after an interview with Haji pilgrims regarding MERS, it was found that only a minority of them were aware about it. Even after advices of the risk, all of them decided to continue their participation [231, 232]. With the increasing prevalence of MERS, in 2014, another study was conducted to test the 
knowledge of healthcare professionals and the outcome was they had good knowledge and positive attitude towards MERS [232]. Similarly, in the study done by Alsahafi and Cheng in 2016, it was found that the knowledge and behaviour towards MERS has decreased drastically [233]. Another study done by Hoda claimed that Saudi communities still lack awareness of available protective measures to prevent the transmission of the virus [234]. However, AlMohrej et al. mentioned that the current public awareness of MERS is generally sufficient. However, some false beliefs about the treatment strategies were common. In addition, almost half of the population remains unaware that bats and camels are the most likely sources of the virus [235]. In a very recently published article, a study conducted back in 2015 once again proved that awareness needs improvement [236]. To assess determinants of psycho-behavioural responses among the general population in Saudi Arabia, a crosssectional survey was conducted at the end of June 2014 which had caused increased anxiety levels in young adults [237].

\section{South Korea}

Meanwhile in South Korea, even though many were worried about the outbreak after the first emergence in 2015 [238], personal and phone interviews were conducted with patients and their guardians to find out about their activities in Saudi Arabia which were investigated with the help of the Saudi Arabian Ministry of Health. From this study, it was concluded that various valuable lessons were learned including the management systems and preventions [92] [239]. A survey via all the mass media in South Korea was conducted which concluded and called for a government-based response system that included provision and dissemination of reliable information about MERS [240, 241]. In the same year, Fung et al. concluded transparent and timely information released to the public is the key for successful health communications to help them prepare better in the future [242].

\section{China}

In china, the social media reaction towards the MERS outbreak study was conducted by Fung et al., and it was found that, compared to H7N9 outbreak, much lesser awareness among the public was seen regarding MERS outbreak. It was also identified that online community reaction was much greater compared to information received from other sources [243].

\section{Oman and Turkey}

In Oman, the preparedness among citizens was analysed after two confirmed cases of MERS infection and through that, infection prevention and control precautions were identified as principal factors to prevent further outbreak and to curb the problem [244]. Sahin et al. studied the knowledge of MERS outbreak among Umrah and Haji pilgrims in Turkey and the result cautioned to increase the importance of basic hygiene principles and measures through well-structured education programmes, both on MERS and on other infectious diseases [245].
However, Mitka et al. suggested that MERS infection is not yet a global worry and recommended the people all around the world to cooperate, to increase awareness regarding this deadly disease [246, 247]. Walker emphasised the need for autopsies as better models for MERS infection [248], whereas Balkhy in his study proved that transformation to control the outbreak is possible if everyone could come together and do their part [60]. Shapiro et al. also mentioned that global preparedness plans and skills are needed to control future outbreaks along with the management of patients and securing the health of people of all around the world [249]. The perception and attitude of healthcare professionals were analysed, and the results stated concerns and the psychological impact of MERS outbreaks should be considered greater deals for the betterment [250].

\section{PREVENTION OF TRANSMISSION}

To control the spread of the outbreak and to prevent the outbreak, efforts for the prevention of transmission of MERS-CoV in healthcare settings and communities are essential. WHO guidelines, as well as detailed reviews on this subject, are readily available [177]. It is pertinent to ensure environmental hygiene, personal hygiene and the importance of implementing precautions against direct contact or droplet contact in healthcare workers. For prevention of community transmission, critical measures namely quarantine, contact tracing, public education and isolation of close contacts are essential [251, 252]. When it comes to hospitals, early detection of the cases must be followed by isolation, preferably an isolation room with negative pressure. The primary infection control and prevention measures for MERS patients are well documented as they overlap with the information obtained from SARS epidemic and the experience gained from handling various MERS outbreaks.

Preventive measures such as personal protective equipment from MERS infection are issued from the Centres for Disease Control and Prevention (CDC) to prevent the transmission of the MERS virus among patients, health care personnel and travellers [253]. El Bushra et al. also stated that a proper way in preventing MERS infection and control (IPC) measures could change the outbreak's course remarkably [254-256].

In 2015, a study was carried out about the concern of MERS outbreak in South Korea. Positive results were shown where higher rates of residents in Korea considered practices of preventive measures that were reliable. Hence, it led to the control the spread of MERS outbreak in Korea [257].

Song et al. stated that an effective communication between government and international partners, about emerging infectious diseases, need to be established to ensure the successfulness in preventing infection risks. CDC in China had done an overall epidemiologic investigation, disinfection of field, communication and cooperation with immigration and security departments to trace closely and quarantine MERS cases. These actions reduced the chance of secondary transmission of MERS-CoV in public as well as in hospitals [258]. 


\section{Patients}

Patients with confirmed MERS infection should be quarantined with necessary precautions. MERS patients who performed aerosol generating procedures were particularly recommended to apply airborne precautions to prevent the transmission of MERS virus to others [25] [136].

\section{Health care personnel}

In Saudi Arabia, a study was carried out by healthcare personnel about the attitudes, awareness, prevention of infection and control policies towards MERS. The results were varied between institutions and different professions. This, however, sparked the actions to minimise the outbreak of MERS [259]. It was also recommended that healthcare personnel should employ the preventive devices and a prophylactic system to prevent dissemination of the emerging virus within health care facilities [260, 261]. Another recommendation was that a response plan for infectious disease emergencies and prevention for optimal infection should be developed in hospitals [262]. Strict standard and airborne precautions are recommended to be a must for healthcare personnel, no matter if the patients are still under investigation or infected with MERS infection [239].

Another recommendation stated that nurses who took care of MERS-CoV-infected patients in the emergency department should be more cautious than other nurses in other departments, because burnout was higher among them. Preparations and efforts must be ready for the outbreak of MERS-CoV to reduce the burnout. Moreover, stress management programmes should be provided to the nurses for good working conditions along with reinforced hospital resources for MERS-CoV treatment. Support from family and friends were also recommended [263].

Use of disinfectants and $70 \%$ alcohol-based sanitizers were recommended for use in hospitals to prevent transmission of MERS-CoV. However, as alcohol evaporated rapidly in air, alcohol was suggested to be applied for sufficient time on the surfaces. Medical devices were also suggested to be used separately for the patients with MERS-CoV infection [264].

\section{Travellers}

Under the advice of the WHO and the CDC [265], travellers were discouraged to travel to the regions where MERS has been detected, to prevent MERS infections [132] [224]. Current information regarding MERS is suggested to be given to the travellers, along with the guidance on how to prevent diseases, especially respiratory diseases [132] [224].The CDC, the WHO and the Ministry of Health (MOH) of Saudi Arabia have advised several preventive measures such as hand hygiene, cough or sneeze by covering nose and mouth with disposable tissues, avoid contact with sick people or people with history travelling to the country in or near Arabian Peninsula and have a healthy lifestyle to increase immunity of the body [212] [266, 267].

It is suggested that travellers should be told to seek for medical services if having any fever or coughing within 2 weeks after returning from the Middle East [261]. Elderly people who are older than 65 years; people with immunodeficiency, chronic diseases and malignant disease; as well as children who are younger than 12 years old and pregnant ladies need to be cautioned [268, 269]. SARS-CoV and MERS-CoV can infect pregnant women, which may result in poor obstetric outcomes, including maternal morbidity and death. No vaccines or specific therapies are currently approved for coronavirus infections [270, 271].

It was concluded in a study that the relationships between labour migration workers and public health authorities were important to ensure the effective preparedness and response planning in response to a potential MERS threat [272-274]. The experiences and lessons encountered in the previous SARS and MERS vaccine research can be used for reference in the development of COVID-19 vaccine [275].

\section{INTENSIVE CARE MANAGEMENT}

Hospital inpatient care is necessitated in severe cases for a reduction in the complication risks pertaining to secondary infections and organ failure. A high failure rate of $92 \%$ associated with non-invasive ventilation is attributable in patients with acute hypoxemic respiratory failure due to MERS-CoV infection [276]. Intensive care unit management might be required for patients who have serious symptoms (acute respiratory distress syndrome) wherein lung-protective ventilatory strategies can be administered. In addition, inotropic support, renal replacement therapy for acute renal failure and antimicrobial therapy for co-infections may be provided.

\section{MENTAL HEALTH SUPPORT}

In a mental health study, out of 1656 patients who had been quarantined, $7.6 \%$ exhibited anxiety symptoms, and frequent bouts of anger were evident in $6.4 \%$ of patients during the 2-week quarantine period [277]. Accurate information, mental health support, adequate supplies of clothes, food and accommodation must be arranged for individuals undergoing isolation.

\section{MANAGEMENT OUTCOMES AND MORTALITY RATES}

Mortality risk factor and disease severity data have been reported by various studies involving patients in South Korea and the Middle East [278-284]. Daily MERS-CoV case information published by the Saudi Arabian Ministry of Health online was collected and studied by Ahmed and colleagues. This data was posted between 2 December 2014 and 12 November 2016, and it reviewed 660 cases of MERS that were laboratory-confirmed [281]. These cases exhibited mortality at day $3(13.8 \%)$, day $30(28.3 \%)$ and overall (29.8\%). As compared to younger patients (20\%), patients who were older than the age of 60 years had a high likelihood of dying $(45.2 \%)$ as a result of the infection. Various factors have been associated with high mortality rates in patients with severe MERS. Some of the most prominent factors include low serum albumin, concomitant infections, positive plasma MERS-CoV RNA, thrombocytopenia, male individuals, lymphopenia and pre-existing comorbid illnesses (such 
as obesity, chronic heart, diabetes mellitus, cancer, lung and kidney disease and immunocompromised states). Patients who suffer from chronic obstructive pulmonary disease or individuals who are smokers have an upregulation in their lung DPP4 receptors. This may explain the reason why patients who have comorbid lung ailments are susceptible to serious ailments [285].

During the Korean outbreak in 2015, the case-fatality rate was $20.4 \%$, as out of 186 patients, 39 died. The 7 -day mortality rate (from symptom onset) was $3.8 \%$ (7 of 186), the in-hospital mortality was $19.4 \%$ (36 of 186 patients) and 28day mortality was $17.7 \%$ (33 of 186) [278] [279]. Factors that were linked with mortality during this outbreak were abnormal renal function, smoking history, older age $(>60$ years), pre-existing pneumonia and comorbidity. When it comes to risk factors for mortality, they included altered mentality, low albumin and high pneumonia severity index score at the time of admission.

\section{PROGNOSIS AND LONG-TERM FOLLOW-UP OF MERS SURVIVORS}

In a study conducted on the post-MERS recovery longterm effects, higher limitations to the quality of life were reported by patients who were admitted to intensive care with serious illness as compared to those who exhibited less severe illness and were managed in medical wards [286]. When it comes to long-term consequences of the MERS on survivors, they appear to be like those which are caused by other severe acute respiratory infections that have been induced by viruses such as parainfluenza, influenza and metapneumovirus [287]. When patients who had recovered from MERS underwent imaging studies, the development of lung fibrosis was observed in a significant number of patients [288].

\section{PRIORITIES FOR MERS RESEARCH, SURVEILLANCE, MANAGEMENT AND CONTROL}

World Organization for Animal Health, Food, and Agriculture Organization of the UN, and the WHO, in consultation with the global MERS prevention bodies have identified priorities and gaps in the knowledge for MERS research, control, surveillance and management. Several studies that were published recently have highlighted the necessity of a one-human-environmental-animal-health (One Health) approach for controlling and tackling the spread of MERS-CoV [177].

\section{LINKAGE BETWEEN SARS-COV-2, SARS-COV AND MERS-COV: AN INSIGHTFUL COMPARISON}

Although the transmission mode of SARS-CoV-2 is still not clear, it is highly possible that all three viruses follow the same mechanism of transmission. The primary mode of transmission between humans is due to the infection via respiratory droplets or secretions of infected individuals. The spreading rate of SARS-CoV-2 is more rapid than that was found during SARS and MERS epidemics, whilst rate of transmission between human-to-human was generally lower for MERS [289].

The case fatality rates (CFRs) across the three viruses range from 0.1 to $34 \%$ with the lowest for SARS-CoV-2 and the highest rate for MERS cases (Table II), although it is crucial to advocate that the CFR for COVID-19 should be deduced meticulously since the outbreak is still ongoing. Considering the mode of transmission, all these viruses are zoonotic in nature. The SARS-CoV reservoir hosts are likely to be bats and MERS-CoV reservoir hosts are dromedary camels. Whilst considering the zoonotic transmission of SARS-CoV-2, it is still a matter of debate, whether the virus was transmitted from an infected snake, palm civet or other animal to human at the Chinese Huanan seafood market [291].

With regard to the origin of these viruses, it is evident that SARS-CoV and SARS-CoV-2 originated from China and they confer a high degree of similarity, such as exposure to wild animals, whilst MERS-CoV and SARS-CoV-2 share similar characteristic features in asymptomatic infections whilst still spreading the disease [290].

COVID-19, SARS and MERS have reported to exhibit several similarities regarding their symptoms, which include cough, fever, fatigue, myalgia and lower respiratory signs.

Table II. General Characteristic Features of SARS-CoV, MERS-CoV and SARS-CoV-2 [290]

\begin{tabular}{llll}
\hline Characteristic features & SARS-CoV & MERS-CoV & SARS-CoV-2 \\
\hline First reported case (year) & 2002 & 2012 & 2019 \\
Place of the origin & China & Middle East & China \\
Transmission modes & Aerosol, droplet and contact & Aerosol, droplet and contact & Aerosol, droplet and contact \\
Natural host & Chinese horseshoe bats & Camels (Probably bats) & Unclear (probably bats) \\
Intermediate Host & Civet cats & Dromedary camels & Unclear (probably pangolins) \\
Host receptor & ACE2 & DPP4 & ACE2 \\
Incubation period & $2-7$ days & $2-14$ days & $2-14$ days \\
Reproduction number $\left(R_{0}\right)$ & Median: 0.58; IQR: 0.24-1.18 & Mean: 0.69 (95\% CI 0.50-0.92) & R0 = 3.1 (coefficient of \\
& & & determination, r2 $=0.99)$ \\
Dominant cell entry pathway & Clathrin- and caveolae- & Cell membrane fusion & Unclear \\
Blood test results & independent endocytic pathway & & Lymphopenia, leucocytosis, \\
& Thrombocytopenia, & Monocytosis, & monocytosis, thrombocytopenia, \\
lymphopenia and leukopenia & leucocytosis and low CRP & leukopenia and low CRP \\
Case fatality rate & $\sim 15 \%$ & $34.40 \%$ & $1-3 \%$
\end{tabular}


However, as the state of illness and disease progresses, the symptoms varied [292]. In order to contain the spread of virus and considering outbreak-managing decisions, on time reporting of cases, updates on clinical status and disposition of patients, the real-time analysis of data and the appropriate distribution of information are essential.

\section{CONCLUSION}

Although medical science has progressed significantly in the past decades, the human race still remains vulnerable towards newly emerging diseases and infections. Transmissions involving the MERS-CoV are not common, yet localised transmissions occur. This topical review has demonstrated the importance of preventive measures to avoid future outbreak of the MERS. There are currently no specific treatments for MERS, but only supportive treatment to individualised patients according to their condition. Nevertheless, several vaccines for MERS-CoV disease are in their developmental stages. Moreover, there exists an urgent need to identify and develop newer advanced targeted therapies to manage future pandemic outbreaks effectively.

\section{REFERENCES}

1. Memish ZA, Perlman S, Van Kerkhove MD, Zumla A. Middle East respiratory syndrome [Internet] 395, The Lancet. Lancet Publishing Group; 2020 [cited 2021 Jan 27] 1063-77. Available from: http://www.thelancet.com/article/S0140673619332210/ fulltext

2. Moh Zaki A, Van Boheemen S, Bestebroer TM, Osterhaus ADME, Fouchier RAM. Isolation of a novel coronavirus from a man with pneumonia in Saudi Arabia. NEJMorg N Engl J Med. 2012;367:1814-34.

3. Alyami MH, Alyami HS, Warraich A. Middle East respiratory syndrome (MERS) and novel coronavirus disease-2019 (COVID-19): from causes to preventions in Saudi Arabia. Saudi Pharmaceutical Journal Elsevier B.V. 2020;28:1481-91.

4. MERS outbreak in Republic of Korea 2015 [cited 2021 Jan 27]. Available from: https://www.who.int/westernpacific/ emergencies/2015-mers-outbreak

5. Middle East respiratory syndrome coronavirus (MERS-CoV) 2021 [cited Jan 27]. Available from: https://www.who.int/ health-topics/middle-east-respiratory-syndrome-coronavirusmers\#tab=tab_1

6. Memish ZA, Mishra N, Olival KJ, Fagbo SF, Kapoor V, Epstein $\mathrm{JH}$, et al. Middle East respiratory syndrome coronavirus in Bats, Saudi Arabia. Emerg Infect Dis. 2013;19(11):1819-23 Nov [cited 2021 Jan 27. Available from: /pmc/articles/PMC3837665/?report=abstract.

7. Ithete NL, Stoffberg S, Corman VM, Cottontail VM, Richards LR, Schoeman MC, et al. Close relative of human Middle East respiratory syndrome coronavirus in bat, South Africa. Emerg Infect Dis. 2013;19(10):1697-9.

8. Mizutani T. A novel coronavirus, MERS-CoV. Uirusu. 2013;63(1):1-6.

9. Lau SK, Li KS, Tsang AK, Lam CS, Ahmed S, Chen H, et al. Genetic characterization of Betacoronavirus lineage $\mathrm{C}$ viruses in bats reveals marked sequence divergence in the spike protein of pipistrellus bat coronavirus HKU5 in Japanese pipistrelle: implications for the origin of the novel Middle East respiratory sy. J Virol. 2013;87(15):8638-50.

10. Anthony SJ, Gilardi K, Menachery VD, Goldstein T, Ssebide B, Mbabazi R, et al. Further evidence for bats as the evolutionary source of Middle East respiratory syndrome coronavirus. MBio. 2017;8(2):e00373-17 Available from: http://www.ncbi.nlm.nih.gov/pmc/articles/PMC5380844/.
11. Cai Y, Yu SQ, Postnikova EN, Mazur S, Bernbaum JG, Burk $\mathrm{R}$, et al. CD26/DPP4 cell-surface expression in bat cells correlates with bat cell susceptibility to Middle East respiratory syndrome coronavirus (MERS-CoV) infection and evolution of persistent infection. PLoS One. 2014;9(11):e112060.

12. Kupferschmidt K. Link to MERS virus underscores bats' puzzling threat. 2013;341:948-9.

13. Widagdo W, Begeman L, Schipper D, Run PRV, Cunningham AA, Kley $\mathrm{N}$, et al. Tissue distribution of the MERScoronavirus receptor in bats. Sci Rep. 2017;7(1):1193.

14. Corman VM, Kallies R, Philipps H, Gopner G, Muller MA, Eckerle I, et al. Characterization of a novel betacoronavirus related to middle East respiratory syndrome coronavirus in European hedgehogs. J Virol. 2014;88(1):717-24.

15. Reusken CB, Ababneh M, Raj VS, Meyer B, Eljarah A, Abutarbush S, et al. Middle East respiratory syndrome coronavirus (MERS-CoV) serology in major livestock species in an affected region in Jordan, June to September 2013. Euro Surveill. 2013/12/18. 2013;18(50):20662.

16. Haagmans BL, Al Dhahiry SHS, Reusken CBEM, Raj VS, Galiano M, Myers R, et al. Middle East respiratory syndrome coronavirus in dromedary camels: an outbreak investigation. Lancet Infect Dis. 2014;14(2):140-5 Available from: http:// www.sciencedirect.com/science/article/pii/S147330991370690X.

17. Yao Y, Bao L, Deng W, Xu L, Li F, Lv Q, et al. An animal model of MERS produced by infection of rhesus macaques with MERS coronavirus. J Infect Dis. 2013/11/13. 2014;209(2):236-42.

18. Nowotny N, Kolodziejek J. Middle East respiratory syndrome coronavirus (MERS-CoV) in dromedary camels, Oman, 2013. Euro Surveill. 2014/05/03. 2014;19(16):20781.

19. van Doremalen N, Hijazeen ZS, Holloway P, Al Omari B, McDowell C, Adney D, et al. High prevalence of Middle East respiratory coronavirus in young dromedary camels in Jordan. Vector Borne Zoonotic Dis. 2016/12/24. 2017;17(2):155-9.

20. Madani TA, Azhar EI, Hashem AM. Evidence for camel-tohuman transmission of MERS coronavirus. N Engl J Med. 2014/10/02. 2014;371(14):1360.

21. Alsolamy S, Arabi YM. Infection with Middle East respiratory syndrome coronavirus. Can J Respir Ther CJRT = Rev Can la Thérapie Respir RCTR. 2015;51(4):102 Available from: http:// www.ncbi.nlm.nih.gov/pmc/articles/PMC4631129/.

22. Chu DK, Oladipo JO, Perera RA, Kuranga SA, Chan SM, Poon LL, et al. Middle East respiratory syndrome coronavirus (MERS-CoV) in dromedary camels in Nigeria. Euro Surveill. 2015/12/18. 2015;20:49.

23. Deem SL, Fevre EM, Kinnaird M, Browne AS, Muloi D, Godeke GJ, et al. Serological evidence of MERS-CoV antibodies in dromedary camels (Camelus dromedaries) in Laikipia County, Kenya. PLoS One. 2015/10/17. 2015;10(10):e0140125.

24. Corman V, Jores J, Meyer B, Younan M, Liljander A, Y Said $\mathrm{M}$, et al. Antibodies against MERS Coronavirus in dromedary Camels, Kenya, 1992-2013. 2014;20.

25. Woo PCY, Lau SKP, Wernery U, Wong EYM, Tsang AKL, Johnson B, et al. Novel betacoronavirus in dromedaries of the Middle East, 2013. Emerg Infect Dis. 2014;20(4):560-72 Available from: http://www.ncbi.nlm.nih.gov/pmc/articles/ PMC3966378/.

26. Wernery U, Corman VM, Wong EY, Tsang AK, Muth D, Lau SK, et al. Acute middle East respiratory syndrome coronavirus infection in livestock dromedaries, Dubai, 2014. Emerg Infect Dis. 2015/05/20. 2015;21(6):1019-22.

27. Gossner C, Danielson N, Gervelmeyer A, Berthe F, Faye B, Kaasik Aaslav K, et al. Human-dromedary camel interactions and the risk of acquiring zoonotic Middle East respiratory syndrome coronavirus infection. Zoonoses Public Health. 2014/12/30. 2016;63(1):1-9.

28. Muller MA, Meyer B, Corman VM, Al-Masri M, Turkestani A, Ritz D, et al. Presence of Middle East respiratory syndrome coronavirus antibodies in Saudi Arabia: a nationwide, crosssectional, serological study. Lancet Infect Dis. 2015/04/13. 2015;15(5):559-64. 
29. A Mohd H, A Al-Tawfiq J, Memish Z. Middle East respiratory syndrome coronavirus (MERS-CoV) origin and animal reservoir. 2016;13.

30. Memish Z, Zumla SPA, A Al-Tawfiq J. How great is the risk of Middle East respiratory syndrome coronavirus to the global population? 2013;11.

31. Balkhair A, Al Maamari K, Alawi FB. The struggle against MERS-CoV (The Novel Coronavirus). Oman Med J. 2013;28(4):226-7 Available from: http://www.ncbi.nlm.nih.gov/ pmc/articles/PMC3725253/.

32. Assiri A, McGeer A, Perl TM, Price CS, Al Rabeeah AA, Cummings DA, et al. Hospital outbreak of Middle East respiratory syndrome coronavirus. N Engl J Med. 2013/06/21. 2013;369(5):407-16.

33. Aleanizy FS, Mohmed N, Alqahtani FY, El Hadi Mohamed RA. Outbreak of Middle East respiratory syndrome coronavirus in Saudi Arabia: a retrospective study. BMC Infect Dis. 2017;17:23 Available from: http://www.ncbi.nlm.nih.gov/pmc/ articles/PMC5217314/.

34. Sherbini N, Iskandrani A, Kharaba A, Khalid G, Abduljawad M, Al-Jahdali H. Middle East respiratory syndrome coronavirus in Al-Madinah City, Saudi Arabia: demographic, clinical and survival data. J Epidemiol Glob Heal. 2016/06/16. 2017;7(1):29-36.

35. Balkhy $\mathrm{HH}$, Alenazi TH, Alshamrani MM, Baffoe-Bonnie $\mathrm{H}$, Al-Abdely HM, El-Saed A, et al. Notes from the field: nosocomial outbreak of Middle East respiratory syndrome in a large tertiary care hospital-Riyadh, Saudi Arabia, 2015. MMWR Morb Mortal Wkly Rep. 2016/02/20. 2016;65(6):1634.

36. Hunter JC, Nguyen D, Aden B, Al Bandar Z, Al Dhaheri W, Abu Elkheir K, et al. Transmission of Middle East respiratory syndrome coronavirus infections in healthcare settings, Abu Dhabi. Emerg Infect Dis. 2016/03/18. 2016;22(4):647-56.

37. Rabaan AA, Al-Ahmed SH, Bazzi AM, Al-Tawfiq JA Dynamics of scientific publications on the MERS-CoV outbreaks in Saudi Arabia. J Infect Public Health. 2017;10(6):70210 Available from: http://www.sciencedirect.com/science/article/pii/S1876034117301387.

38. Yousefi M, Dehesh MM, Farokhnia M. Epidemiological and clinical characteristics of patients with Middle East respiratory syndrome coronavirus in Iran in 2014. Jpn J Infect Dis. 2016/05/14. 2017;70(1):115-8.

39. Yavarian J, Rezaei F, Shadab A, Soroush M, Mehdi Gooya M, Mokhtari-Azad T. Cluster of Middle East respiratory syndrome coronavirus infections in Iran, 2014. 2015;21:362-4.

40. Gautret P, Benkouiten S, Al-Tawfiq JA, Memish ZA. The spectrum of respiratory pathogens among returning Hajj pilgrims: myths and reality. Int J Infect Dis. 2016;47(Supplement C):83-5 Available from: http://www.sciencedirect.com/ science/article/pii/S120197121600014X.

41. Puzelli S, Azzi A, Santini MG, Di Martino A, Facchini M, Castrucci MR, et al. Investigation of an imported case of Middle East respiratory syndrome coronavirus (MERS-CoV) infection in Florence, Italy, May to June 2013. Euro Surveill. 2013/08/31. 2013;18(34).

42. Kraaij-Dirkzwager M, Timen A, Dirksen K, Gelinck L, Leyten E, Groeneveld P, et al. Middle East respiratory syndrome coronavirus (MERS-CoV) infections in two returning travellers in the Netherlands, May 2014. Euro Surveill. 2014/06/08. 2014;19(21).

43. Tsiodras S, Baka A, Mentis A, Iliopoulos D, Dedoukou X, Papamavrou G, et al. A case of imported Middle East respiratory syndrome coronavirus infection and public health response, Greece, April 2014. Euro Surveill. 2014/05/03. 2014;19(16):20782.

44. Park Y-S, Lee C, Kim KM, Kim SW, Lee K-J, Ahn J, et al. The first case of the 2015 Korean Middle East respiratory syndrome outbreak. Epidemiol Health. 2015;37:e2015049 Available from: http://www.ncbi.nlm.nih.gov/pmc/articles/ PMC4722220/.

45. Cowling BJ, Park M, Fang VJ, Wu P, Leung GM, Wu JT. Preliminary epidemiological assessment of MERS-CoV outbreak in South Korea, May to June 2015. Euro Surveill. 2015/07/02. 2015;20(25):7-13.
46. Lee J. Better understanding on MERS corona virus outbreak in Korea. J Korean Med Sci. 2015;30(7):835-6 Available from: http://www.ncbi.nlm.nih.gov/pmc/articles/PMC4479933/.

47. Park JW, Lee KJ, Lee KH, Lee SH, Cho JR, Mo JW, et al. Hospital outbreaks of Middle East respiratory syndrome, Daejeon, South Korea, 2015. Emerg Infect Dis. 2017/05/19. 2017;23(6):898-905.

48. Park SH, Kim YS, Jung Y, Choi SY, Cho NH, Jeong HW, et al. Outbreaks of Middle East respiratory syndrome in two hospitals initiated by a single patient in Daejeon, South Korea. Infect Chemother. 2016;48(2):99-107.

49. Yong CJ. An outbreak of Middle East respiratory syndrome coronavirus infection in South Korea. 2015;56:1174-6.

50. Choi JH, Yoo B, Lee SY, Lee EG, Ki M, Lee W, et al. Epidemiological investigation of the 119th confirmed Middle East respiratory Syndrome coronavirus case with an indefinite mode of transmission during the Pyeongtaek outbreak in Korea. Epidemiol Health. 2015;37:e2015054 Available from: http://www.ncbi.nlm.nih.gov/pmc/articles/PMC4789606/.

51. Oh M, Choe PG, Oh HS, Park WB, Lee S-M, Park J, et al. Middle East respiratory syndrome coronavirus superspreading event involving 81 persons, Korea 2015. J Korean Med Sci. 2015;30(11):1701-5 Available from: http:// www.ncbi.nlm.nih.gov/pmc/articles/PMC4630490/.

52. Chang K, Ki M, Lee EG, Lee SY, Yoo B, Choi JH. MERS epidemiological investigation to detect potential mode of transmission in the 178th MERS confirmed case in Pyeongtaek, Korea. Epidemiol Heal. 2015/10/24. 2015;37:e2015036.

53. Yang JS, Park S, Kim YJ, Kang HJ, Kim H, Han YW, et al. Middle East respiratory syndrome in 3 persons, South Korea, 2015. Emerg Infect Dis. 2015/10/22. 2015;21(11):2084-7.

54. Kim D-H. Structural factors of the Middle East respiratory syndrome coronavirus outbreak as a public health crisis in Korea and future response strategies. J Prev Med Public Heal. $2015 ; 48(6): 265-70$ Available from: http:// www.ncbi.nlm.nih.gov/pmc/articles/PMC4676643/.

55. Kim KM, Ki M, Cho SI, Sung M, Hong JK, Cheong HK, et al. Epidemiologic features of the first MERS outbreak in Korea: focus on Pyeongtaek St. Mary's Hospital. Epidemiol Heal. 2016/01/05. 2015;37:e2015041.

56. Ki M. MERS outbreak in Korea: hospital-to-hospital transmission. Epidemiol Health. 2015;37:e2015033 Available from: http://www.ncbi.nlm.nih.gov/pmc/articles/PMC4533026/.

57. Kim SH, Chang SY, Sung M, Park JH, Bin Kim H, Lee H, et al. Extensive viable Middle East respiratory syndrome (MERS) coronavirus contamination in air and surrounding environment in MERS Isolation Wards. Clin Infect Dis. 2016/04/20. 2016;63(3):363-9.

58. Racelis S, De los Reyes VC, Sucaldito MN, Deveraturda I, Roca JB, Tayag E. Contact tracing the first Middle East respiratory syndrome case in the Philippines, February 2015. West Pacific Surveill Response J WPSAR. 2015;6(3):3-7 Available from: http://www.ncbi.nlm.nih.gov/pmc/articles/ PMC4675163/.

59. Koenig KL. Identify-Isolate-Inform: a modified tool for initial detection and management of Middle East respiratory syndrome patients in the emergency department. West J Emerg Med. 2015/11/21. 2015;16(5):619-24.

60. Su S, Wong G, Liu Y, Gao GF, Li S, Bi Y. MERS in South Korea and China: a potential outbreak threat? Lancet. 2015/06/20. 2015;385(9985):2349-50.

61. Updated information on the epidemiology of Middle East respiratory syndrome coronavirus (MERS-CoV) infection and guidance for the public, clinicians, and public health authorities. MMWR Morb Mortal Wkly Rep. 2013;62(38):793-6.

62. van Doremalen N, Bushmaker T, Munster VJ. Stability of Middle East respiratory syndrome coronavirus (MERS-CoV) under different environmental conditions. Euro Surveill. 2013/10/03. 2013;18(38).

63. Goh GK, Dunker AK, Uversky V. Prediction of intrinsic disorder in MERS-CoV/HCoV-EMC supports a high oral-fecal transmission. PLoS Curr. 2013;5. 
64. Hui DS, Zumla A. Advancing priority research on the Middle East respiratory syndrome coronavirus. J Infect Dis. 2014;209(2):173-6.

65. Poletto C, Pelat C, Levy-Bruhl D, Yazdanpanah Y, Boelle P-Y, Colizza V. Assessment of the Middle East respiratory syndrome coronavirus (MERS-CoV) epidemic in the Middle East and risk of international spread using a novel maximum likelihood analysis approach. 2014;19.

66. Memish ZA, Cotten M, Meyer B, Watson SJ, Alsahafi AJ, Al Rabeeah AA, et al. Human infection with MERS coronavirus after exposure to infected camels, Saudi Arabia, 2013. Emerg Infect Dis. 2014;20(6):1012-5.

67. Memish ZA, Alsahly A, Masri MA, Heil GL, Anderson BD, Peiris $\mathrm{M}$, et al. Sparse evidence of MERS-CoV infection among animal workers living in Southern Saudi Arabia during 2012. Influenza Other Respir Viruses. 2015;9(2):64-7.

68. Aburizaiza AS, Mattes FM, Azhar EI, Hassan AM, Memish ZA, Muth D, et al. Investigation of anti-middle East respiratory syndrome antibodies in blood donors and slaughterhouse workers in Jeddah and Makkah, Saudi Arabia, fall 2012. J Infect Dis. 2014;209(2):243-6.

69. Reusken CB, Farag EA, Jonges M, Godeke GJ, El-Sayed AM, Pas SD, et al. Middle East respiratory syndrome coronavirus (MERS-CoV) RNA and neutralising antibodies in milk collected according to local customs from dromedary camels, Qatar, April 2014. Euro Surveill. 2014;19(23).

70. Yang Y, Liu C, Du L, Jiang S, Shi Z, Baric RS, et al. Two mutations were critical for bat-to-human transmission of Middle East respiratory syndrome coronavirus. J Virol. 2015;89(17):9119-23.

71. Breban R, Riou J, Fontanet A. Interhuman transmissibility of Middle East respiratory syndrome coronavirus: estimation of pandemic risk. Lancet. 2013;382(9893):694-9.

72. Cauchemez S, Fraser C, Van Kerkhove MD, Donnelly CA, Riley S, Rambaut A, et al. Middle East respiratory syndrome coronavirus: quantification of the extent of the epidemic, surveillance biases, and transmissibility. Lancet Infect Dis. 2014;14(1):50-6 Available from: http://www.ncbi.nlm.nih.gov/ pmc/articles/PMC3895322/.

73. Memish ZA, Zumla AI, Al-Hakeem RF, Al-Rabeeah AA, Stephens GM. Family cluster of Middle East respiratory syndrome coronavirus infections. N Engl J Med. 2013;368(26):2487-94 Available from: http://www.nejm.org/ doi/full/10.1056/NEJMoa1303729.

74. Drosten C, Meyer B, Müller M, Corman V, Al-Masri M, Hussain R, et al. Transmission of MERS-coronavirus in household contacts. 371 2014. 828-835.

75. Memish ZA, Al-Tawfiq JA, Makhdoom HQ, Al-Rabeeah AA, Assiri A, Alhakeem RF, et al. Screening for Middle East respiratory syndrome coronavirus infection in hospital patients and their healthcare worker and family contacts: a prospective descriptive study. Clin Microbiol Infect. 2014;20(5):469-74.

76. Hijawi B, Abdallat M, Sayaydeh A, Alqasrawi S, Haddadin A, Jaarour N, et al. Novel coronavirus infections in Jordan, April 2012: epidemiological findings from a retrospective investigation. East Mediterr Health J. 2013;19(Suppl 1):S12-8.

77. Assiri A, Al-Tawfiq JA, Al-Rabeeah AA, Al-Rabiah FA, AlHajjar S, Al-Barrak A, et al. Epidemiological, demographic, and clinical characteristics of 47 cases of Middle East respiratory syndrome coronavirus disease from Saudi Arabia: a descriptive study. Lancet Infect Dis. 2013/07/31. 2013;13(9):752-61.

78. Al-Abdallat MM, Payne DC, Alqasrawi S, Rha B, Tohme RA, Abedi GR, et al. Hospital-associated outbreak of Middle East respiratory syndrome coronavirus: a serologic, epidemiologic, and clinical description. Clin Infect Dis. 2014/05/16. 2014;59(9):1225-33.

79. Evidence of person-to-person transmission within a family cluster of novel coronavirus infections, United Kingdom Euro Surveill 2013;18(11):20427.

80. Guery B, Poissy J, el Mansouf L. Clinical features and viral diagnosis of two cases of infection with Middle East Respiratory Sydrome coronavirus: a report of nosocomial transmission $20133812254-2265$
81. Al-Tawfiq JA. Middle East respiratory syndrome-coronavirus infection: an overview. J Infect Public Health. 2013;6(5):319-22 Available from: http://www.sciencedirect.com/science/article/ pii/S1876034113000890.

82. A. Gastanaduy P. Update Severe respiratory illness associated with Middle East respiratory syndrome coronavirus (MERSCoV)worldwide 2012-2013 13 2492-2495

83. Harriman K, Brosseau L, Trivedi K. Hospital-associated Middle East respiratory syndrome coronavirus infections. N Engl J Med 2013;369(18):1761.

84. Memish ZA, Al-Tawfiq JA, Assiri A. Hospital-associated Middle East respiratory syndrome coronavirus infections. N Engl J Med 2013;369(18):1761-2.

85. Sampathkumar P. Middle East respiratory syndrome: what clinicians need to know. Mayo Clin Proc 2014;89(8):1153-8.

86. Al-Gethamy M, Corman VM, Hussain R, Al-Tawfiq JA, Drosten C, Memish ZA. A case of long-term excretion and subclinical infection with Middle East respiratory syndrome coronavirus in a healthcare worker. Clin Infect Dis. 2015;60(6):973-4.

87. Lee SS, Wong NS. Probable transmission chains of Middle East respiratory syndrome coronavirus and the multiple generations of secondary infection in South Korea. Int J Infect Dis. 2015;38:65-7.

88. Memish ZA, Zumla AI, Assiri A. Middle East respiratory syndrome coronavirus infections in health care workers. N Engl J Med. 2013;369(9):884-6.

89. Middle East respiratory syndrome coronavirus outbreak in the Republic of Korea, 2015. Osong Public Heal Res Perspect. 2015;6(4):269-78.

90. Banik GR, Khandaker G, Rashid H. Middle East respiratory syndrome coronavirus "MERS-CoV": current knowledge gaps. Paediatr Respir Rev. 2015;16(3):197-202 Available from: http://www.sciencedirect.com/science/article/pii/ S1526054215000317.

91. Xia ZQ, Zhang J, Xue YK, Sun GQ, Jin Z. Modeling the transmission of Middle East respirator syndrome corona virus in the Republic of Korea. PLoS One. 2015;10(12):e0144778.

92. Kim KH, Tandi TE, Choi JW, Moon JM, Kim MS. Middle East respiratory syndrome coronavirus (MERS-CoV) outbreak in South Korea, 2015: epidemiology, characteristics and public health implications. J Hosp Infect. 2017;95(2):207-13.

93. Jansen A, Chiew M, Konings F, Lee CK, Ailan L. Sex matters - a preliminary analysis of Middle East respiratory syndrome in the Republic of Korea, 2015. West Pac Surveill Response J. 2015;6(3):68-71.

94. Shapiro M, London B, Nigri D, Shoss A, Zilber E, Fogel I. Middle East respiratory syndrome coronavirus: review of the current situation in the world 20162.

95. Sha J, Li Y, Chen X, Hu Y, Ren Y, Geng X, et al. Fatality risks for nosocomial outbreaks of Middle East respiratory syndrome coronavirus in the Middle East and South Korea. Arch Virol. 2017;162(1):33-44.

96. Feikin DR, Alraddadi B, Qutub M, Shabouni O, Curns A, Oboho IK, et al. Association of higher MERS-CoV virus load with severe disease and death, Saudi Arabia, 2014. Emerg Infect Dis. 2015;21(11):2029-35.

97. Thabet F, Chehab M, Bafaqih H, AlMohaimeed S. Middle East respiratory syndrome coronavirus in children. Saudi Med J. 2015;36(4):484-6 Available from: http:// www.ncbi.nlm.nih.gov/pmc/articles/PMC4404484/.

98. Majumder MS, Kluberg SA, Mekaru SR, Brownstein JS. Mortality risk factors for Middle East respiratory syndrome outbreak, South Korea, 2015. Emerg Infect Dis. 2015;21(11):2088-90.

99. Mizumoto K, Endo A, Chowell G, Miyamatsu Y, Saito M, Nishiura H. Real-time characterization of risks of death associated with the Middle East respiratory syndrome (MERS) in the Republic of Korea, 2015 13. 2015.

100. Chan JF, Lau SK, To KK, Cheng VC, Woo PC, Yuen KY. Middle East respiratory syndrome coronavirus: another zoonotic betacoronavirus causing SARS-like disease. Clin Microbiol Rev. 2015;28(2):465-522.

101. Momattin H, Mohammed K, Zumla A, Memish ZA, Al-Tawfiq JA. Therapeutic options for Middle East respiratory syndrome 
coronavirus (MERS-CoV) - possible lessons from a systematic review of SARS-CoV therapy. Int $J$ Infect Dis. 2013;17(10):e792-8 Available from: http:// www.sciencedirect.com/science/article/pii/S1201971213002294.

102. Alraddadi BM, Watson JT, Almarashi A, Abedi GR, Turkistani A, Sadran M, et al. Risk factors for primary Middle East respiratory syndrome coronavirus illness in humans, Saudi Arabia, 2014. Emerg Infect Dis. 2016;22(1):49-55.

103. Kim SW, Park JW, Jung HD, Yang JS, Park YS, Lee C, et al. Risk factors for transmission of Middle East respiratory syndrome coronavirus infection during the 2015 outbreak in South Korea. Clin Infect Dis. 2017;64(5):551-7.

104. M Alraddadi BS, Al-Salmi H, Jacobs-Slifka K, Slayton RF, Estivariz CI. Geller A, et al. Risk Factors for Middle East respiratory syndrome coronavirus infection among healthcare personnel. 201622

105. Alfaraj SH, Al-Tawfiq JA, Altuwaijri TA, Alanazi M, Alzahrani N, Memish ZA. Middle East respiratory syndrome coronavirus transmission among health care workers: Implication for infection control. Am J Infect Control [Internet]. 2017; Available from: http://www.sciencedirect.com/science/article/ pii/S0196655317309574

106. Omrani AS, Shalhoub S. Middle East respiratory syndrome coronavirus (MERS-CoV): what lessons can we learn? J Hosp Infect. 2015;91(3):188-96.

107. Maltezou HC, Tsiodras S. Middle East respiratory syndrome coronavirus: implications for health care facilities. Am J Infect Control. 2014;42(12):1261-5 Available from: http:// www.sciencedirect.com/science/article/pii/S0196655314009316.

108. State of knowledge and data gaps of Middle East respiratory syndrome coronavirus (MERS-CoV) in humans. PLoS Curr. 2013;5.

109. Xie Q, Cao Y, Su J, Wu J, Wu X, Wan C, et al. Two deletion variants of Middle East respiratory syndrome coronavirus found in a patient with characteristic symptoms. Arch Virol. 2017;162(8):2445-9.

110. Omrani AS, Matin MA, Haddad Q, Al-Nakhli D, Memish ZA, Albarrak AM. A family cluster of Middle East respiratory syndrome coronavirus infections related to a likely unrecognized asymptomatic or mild case. Int J Infect Dis. 2013;17(9):e668-72 Available from: http://www.sciencedirect.com/science/article/pii/ S1201971213002257.

111. Kang CK, Song K-H, Gyun Choe P, Beom Park W, Hwan Bang J, Kim ES, et al. Clinical and epidemiologic characteristics of spreaders of Middle East respiratory syndrome coronavirus during the 2015 outbreak in Korea. 201730744.

112. Kim SH, Ko JH, Park GE, Cho SY, Ha YE, Kang JM, et al. Atypical presentations of MERS-CoV infection in immunocompromised hosts. J Infect Chemother. 2017;23(11):769-73.

113. Lu G, Hu Y, Wang Q, Qi J, Gao F, Li Y, et al. Molecular basis of binding between novel human coronavirus MERS-CoV and its receptor CD26. Nature. 2013;500(7461):227-31.

114. Kandeel M, Elaiziz MA, Kandeel A, Altaher AA, Kitade Y. Association of host tropism of Middle East syndrome coronavirus with the amino acid structure of host cell receptor dipeptidyl peptidase 4. Acta Virol. 2014;58(4):359-63.

115. Raj VS, Mou H, Smits SL, Dekkers DH, Muller MA, Dijkman $\mathrm{R}$, et al. Dipeptidyl peptidase 4 is a functional receptor for the emerging human coronavirus-EMC. Nature. 2013;495(7440):251-4.

116. Boonacker E, Van Noorden CJ. The multifunctional or moonlighting protein CD26/DPPIV. Eur J Cell Biol. 2003;82(2):53-73.

117. Zhao G, Jiang Y, Qiu H, Gao T, Zeng Y, Guo Y, et al. Multiorgan damage in human dipeptidyl peptidase 4 transgenic mice infected with Middle East respiratory syndrome-coronavirus. PLoS One. 2015;10(12):e0145561.

118. Xia Z-Q, Zhang J, Xue Y-K, Sun G-Q, Jin Z. Modeling the transmission of middle east respirator syndrome corona virus in the Republic of Korea. PLoS One . 2015;10(12):e0144778. Available from: http://www.ncbi.nlm.nih.gov/pmc/articles/ PMC4686901/

119. Agrawal AS, Garron T, Tao X, Peng BH, Wakamiya M, Chan $\mathrm{TS}$, et al. Generation of a transgenic mouse model of Middle
East respiratory syndrome coronavirus infection and disease. $\mathrm{J}$ Virol. 2015;89(7):3659-70.

120. Hocke AC, Becher A, Knepper J, Peter A, Holland G, Tonnies M, et al. Emerging human middle East respiratory syndrome coronavirus causes widespread infection and alveolar damage in human lungs. Am J Respir Crit Care Med. 2013;188(7):882-6.

121. Baseler LJ, Falzarano D, Scott DP, Rosenke R, Thomas T, Munster VJ, et al. An acute immune response to Middle East respiratory syndrome coronavirus replication contributes to viral pathogenicity. Am J Pathol. 2016;186(3):630-8.

122. Meyerholz DK, Lambertz AM, McCray PB. Dipeptidyl peptidase 4 distribution in the human respiratory tract implications for the Middle East respiratory syndrome. Am J Pathol [Internet]. 2016 Jan 1 [cited 2021 Jan 27];186(1):78-86. Available from: https://pubmed.ncbi.nlm.nih.gov/26597880/

123. Yu P, Xu Y, Deng W, Bao L, Huang L, Xu Y, et al. Comparative pathology of rhesus macaque and common marmoset animal models with Middle East respiratory syndrome coronavirus. PLoS One. 2017;12(2):e0172093.

124. Bosch BJ, Raj VS, Haagmans BL. Spiking the MERScoronavirus receptor. Cell Res. 2013;23(9):1069-70.

125. Xia S, Liu Q, Wang Q, Sun Z, Su S, Du L, et al. Middle East respiratory syndrome coronavirus (MERS-CoV) entry inhibitors targeting spike protein. Virus Res. 2014;194(Supplement C):200-10. Available from: http://www.sciencedirect.com/science/article/pii/S0168170214004122

126. Lu L, Liu Q, Zhu Y, Chan KH, Qin L, Li Y, et al. Structurebased discovery of Middle East respiratory syndrome coronavirus fusion inhibitor. Nat Commun. 2014;5:3067.

127. Gao J, Lu G, Qi J, Li Y, Wu Y, Deng Y, et al. Structure of the fusion core and inhibition of fusion by a heptad repeat peptide derived from the $\mathrm{S}$ protein of Middle East respiratory syndrome coronavirus. J Virol. 2013;87(24):13134-40.

128. Millet JK, Whittaker GR. Host cell entry of Middle East respiratory syndrome coronavirus after two-step, furinmediated activation of the spike protein. Proc Natl Acad Sci U S A. 2014;111(42):15214-9.

129. Kim Y, Cheon S, Min C-K, Sohn KM, Kang YJ, Cha Y-J, et al. Spread of mutant Middle East respiratory syndrome coronavirus with reduced affinity to human CD26 during the South Korean outbreak. MBio. 2016;7(2):e00019-6 Available from: http://www.ncbi.nlm.nih.gov/pmc/articles/PMC4810480/.

130. Yang Y, Zhang L, Geng H, Deng Y, Huang B, Guo Y, et al. The structural and accessory proteins M, ORF 4a, ORF 4b, and ORF 5 of Middle East respiratory syndrome coronavirus (MERS-CoV) are potent interferon antagonists. Protein Cell. 2013;4(12):951-61.

131. Yang Y, Ye F, Zhu N, Wang W, Deng Y, Zhao Z, et al. Middle East respiratory syndrome coronavirus ORF4b protein inhibits type I interferon production through both cytoplasmic and nuclear targets. Sci Rep. 2015;5:17554.

132. Chan RW, Chan MC, Agnihothram S, Chan LL, Kuok DI, Fong JH, et al. Tropism of and innate immune responses to the novel human betacoronavirus lineage $\mathrm{C}$ virus in human ex vivo respiratory organ cultures. J Virol. 2013;87(12):6604-14.

133. Lau SK, Lau CC, Chan KH, Li CP, Chen H, Jin DY, et al. Delayed induction of proinflammatory cytokines and suppression of innate antiviral response by the novel Middle East respiratory syndrome coronavirus: implications for pathogenesis and treatment. J Gen Virol. 2013;94(Pt 12):2679-90.

134. Subbaram K, Kannan H, Khalil GM. Emerging developments on pathogenicity, molecular virulence, epidemiology and clinical symptoms of current Middle East respiratory syndrome coronavirus (MERS-CoV). HAYATI J Biosci. 2017;24(2):53-6 Available from: http://www.sciencedirect.com/science/article/ pii/S1978301917301158.

135. Mielech AM, Kilianski A, Baez-Santos YM, Mesecar AD, Baker SC. MERS-CoV papain-like protease has deISGylating and deubiquitinating activities. Virology. 2014;450-451:64-70.

136. Yang X, Chen X, Bian G, Tu J, Xing Y, Wang Y. Proteolytic processing, deubiquitinase and interferon antagonist activities of Middle East respiratory syndrome coronavirus papain-like protease. J Gen Virol. 2014;95. Available from. https://doi.org/ 10.1099/vir.0.059014-0. 
137. Chu H, Zhou J, Wong BH, Li C, Cheng ZS, Lin X, et al. Productive replication of Middle East respiratory syndrome coronavirus in monocyte-derived dendritic cells modulates innate immune response. Virology. 2014;454-455:197-205.

138. Tynell J, Westenius V, Ronkko E, Munster VJ, Melen K, Osterlund $\mathrm{P}$, et al. Middle East respiratory syndrome coronavirus shows poor replication but significant induction of antiviral responses in human monocyte-derived macrophages and dendritic cells. J Gen Virol. 2016;97(2):344-55.

139. Chu H, Zhou J, Wong BH, Li C, Chan JF, Cheng ZS, et al. Middle East respiratory syndrome coronavirus efficiently infects human primary $\mathrm{T}$ lymphocytes and activates the extrinsic and intrinsic apoptosis pathways. J Infect Dis. 2016;213(6):904-14.

140. Scheuplein VA, Seifried J, Malczyk AH, Miller L, Hocker L, Vergara-Alert J, et al. High secretion of interferons by human plasmacytoid dendritic cells upon recognition of Middle East respiratory syndrome coronavirus. J Virol. 2015;89(7):3859-69.

141. Zhong J, Rao X, Rajagopalan S. An emerging role of dipeptidyl peptidase 4 (DPP4) beyond glucose control: potential implications in cardiovascular disease. Atherosclerosis. 2013;226(2):305-14.

142. Coleman CM, Sisk JM, Halasz G, Zhong J, Beck SE, Matthews KL, et al. CD8+ T cells and macrophages regulate pathogenesis in a mouse model of Middle East respiratory syndrome. J Virol. 2017;91(1).

143. Zhao J, Li K, Wohlford-Lenane C, Agnihothram SS, Fett C, Zhao $\mathrm{J}$, et al. Rapid generation of a mouse model for Middle East respiratory syndrome. Proc Natl Acad Sci U S A. 2014;111(13):4970-5 Available from: http://www.ncbi.nlm.nih.gov/ pmc/articles/PMC3977243/.

144. de Wit E, Rasmussen AL, Falzarano D, Bushmaker T, Feldmann F, Brining DL, et al. Middle East respiratory syndrome coronavirus (MERS-CoV) causes transient lower respiratory tract infection in rhesus macaques. Proc Natl Acad Sci U S A. 2013;110(41):16598-603 Available from: http:// www.ncbi.nlm.nih.gov/pmc/articles/PMC3799368/.

145. Malik A, El Masry KM, Ravi M, Sayed F. Middle East respiratory syndrome coronavirus during pregnancy, Abu Dhabi, United Arab Emirates, 2013. Emerg Infect Dis. 2016;22(3):515-7.

146. Alserehi H, Wali G, Alshukairi A, Alraddadi B. Impact of Middle East respiratory syndrome coronavirus (MERS-CoV) on pregnancy and perinatal outcome. BMC Infect Dis. 2016;16:105.

147. Assiri A, Abedi GR, Al Masri M, Bin Saeed A, Gerber SI, Watson JT. Middle East respiratory syndrome coronavirus infection during pregnancy: a report of 5 cases from Saudi Arabia. Clin Infect Dis. 2016;63(7):951-3.

148. Al-Hameed FM. Spontaneous intracranial hemorrhage in a patient with Middle East respiratory syndrome corona virus. Saudi Med J. 2017;38(2):196-200 Available from: http:// www.ncbi.nlm.nih.gov/pmc/articles/PMC5329633/.

149. Li K, Wohlford-Lenane C, Perlman S, Zhao J, Jewell AK, Reznikov LR, et al. Middle East respiratory syndrome coronavirus causes multiple organ damage and lethal disease in mice transgenic for human dipeptidyl peptidase 4. J Infect Dis. 2016;213(5):712-22.

150. Rasmussen SA, Smulian JC, Lednicky JA, Wen TS, Jamieson DJ. Coronavirus disease 2019 (COVID-19) and pregnancy: what obstetricians need to know. American Journal of Obstetrics and Gynecology. Mosby Inc. 2020222 415-26.

151. Mohamed DH, AlHetheel AF, Mohamud HS, Aldosari K, Alzamil FA, Somily AM. Clinical validation of 3 commercial real-time reverse transcriptase polymerase chain reaction assays for the detection of Middle East respiratory syndrome coronavirus from upper respiratory tract specimens. Diagn Microbiol Infect Dis. 2017;87(4):320-4.

152. Alhetheel A, Altalhi H, Albarrag A, Shakoor Z, Mohamed D, El-Hazmi M, et al. Assessing the detection of Middle East respiratory syndrome coronavirus $\mathrm{IgG}$ in suspected and proven cases of Middle East respiratory syndrome coronavirus infection. 201730.

153. Cha R, Joh J-S, Jeong I, Lee JY, Shin H-S, Kim G, et al. Renal complications and their prognosis in Korean patients with
Middle East respiratory syndrome-coronavirus from the central MERS-CoV designated hospital. J Korean Med Sci. 2015;30(12):1807-14 Available from: http:// www.ncbi.nlm.nih.gov/pmc/articles/PMC4689825/.

154. Abd El Wahed A, Patel P, Heidenreich D, Hufert FT, Weidmann M. Reverse transcription recombinase polymerase amplification assay for the detection of middle East respiratory syndrome coronavirus. PLoS Curr. 20135.

155. Yaren O, Glushakova LG, Bradley KM, Hoshika S, Benner SA. Standard and AEGIS nicking molecular beacons detect amplicons from the Middle East respiratory syndrome coronavirus. J Virol Methods [Internet]. 2016;236(Supplement C):5461. Available from: http://www.sciencedirect.com/science/article/pii/S0166093416300180

156. Muhairi SA, Hosani FA, Eltahir YM, Mulla MA, Yusof MF, Serhan WS, et al. Epidemiological investigation of Middle East respiratory syndrome coronavirus in dromedary camel farms linked with human infection in Abu Dhabi Emirate, United Arab Emirates. Virus Genes. 2016;52(6):848-54.

157. Al Hammadi ZM, Chu DK, Eltahir YM, Al Hosani F, Al Mulla M, Tarnini W, et al. Asymptomatic MERS-CoV infection in humans possibly linked to infected dromedaries imported from Oman to United Arab Emirates, May 2015. Emerg Infect Dis. 2015;21(12):2197-200.

158. Heyuan G, Tan W. A novel human coronavirus: Middle East respiratory syndrome human coronavirus. 201356 683-687

159. Pereyaslov D, Rosin P, Palm D, Zeller H, Gross D, Brown CS, et al. Laboratory capability and surveillance testing for Middle East respiratory syndrome coronavirus infection in the WHO European Region, June 2013. Euro Surveill. 2014;19(40):20923.

160. Douglas CE, Kulesh DA, Jaissle JG, Minogue TD. Real-time reverse transcriptase polymerase chain reaction assays for Middle East Respiratory Syndrome. Mol Cell Probes. 2015;29(6):511-3 Available from: http://www.sciencedirect.com/science/article/pii/ S0890850815300347.

161. Khuri-Bulos N, Payne DC, Lu X, Erdman D, Wang L, Faouri $\mathrm{S}$, et al. Middle East respiratory syndrome coronavirus not detected in children hospitalized with acute respiratory illness in Amman, Jordan, March 2010 to September 2012. Clin Microbiol Infect. 2014;20(7):678-82 Available from: http:// www.sciencedirect.com/science/article/pii/S1198743X14611575.

162. Hashemzadeh MS, Rasouli R, Zahraei B, Izadi M, Tat M, Saadat SH, et al. Development of dual TaqMan based one-step rRT-PCR assay panel for rapid and accurate diagnostic test of MERS-CoV: a novel human coronavirus, ahead of Hajj Pilgrimage. Iran Red Crescent Med J. 2016;18(11):e23874. Available from: http://www.ncbi.nlm.nih.gov/pmc/articles/ PMC5292137/

163. Zhang L, Hao M, Zhang K, Zhang R, Lin G, Jia T, et al. External quality assessment for the molecular detection of MERS-CoV in China. J Clin Virol. 2016;75(Supplement C):59. Available from: http://www.sciencedirect.com/science/article/ pii/S1386653215007830

164. Milne-Price S, Miazgowicz KL, Munster VJ. The emergence of the Middle East respiratory syndrome coronavirus (MERSCoV). Pathog Dis. 2014;71(2):119-34 Available from: http:// www.ncbi.nlm.nih.gov/pmc/articles/PMC4106996/.

165. Huh HJ, Ko J-H, Kim Y-E, Park C-H, Hong G, Choi R, et al. Importance of specimen type and quality in diagnosing Middle East respiratory syndrome. Ann Lab Med. 2017;37(1):81-3 Available from: http://www.ncbi.nlm.nih.gov/pmc/articles/ PMC5107625/.

166. Ki C-S, Lee H, Sung H, Kim S, Seong M-W, Yong D, et al. Korean Society for Laboratory Medicine Practice Guidelines for the Molecular Diagnosis of Middle East Respiratory Syndrome During an Outbreak in Korea in 2015. 2016;36:203.

167. Corman VM, Olschlager S, Wendtner CM, Drexler JF, Hess $\mathrm{M}$, Drosten C. Performance and clinical validation of the RealStar MERS-CoV Kit for detection of Middle East respiratory syndrome coronavirus RNA. J Clin Virol. 2014;60(2):168-71.

168. Coleman CM, Matthews KL, Goicochea L, Frieman MB. Wildtype and innate immune-deficient mice are not susceptible to the Middle East respiratory syndrome coronavirus. J Gen 
Virol. 2014;95. Available from. https://doi.org/10.1099/ vir.0.060640-0.

169. Lee SH, Baek YH, Kim Y-H, Choi Y-K, Song M-S, Ahn J-Y. One-pot reverse transcriptional loop-mediated isothermal amplification (RT-LAMP) for detecting MERS-CoV. Front Microbiol. 2016;7:2166. Available from: http:// www.ncbi.nlm.nih.gov/pmc/articles/PMC5220095/

170. Gierer S, Hofmann-Winkler H, Albuali WH, Bertram S, AlRubaish AM, Yousef AA, et al. Lack of MERS coronavirus neutralizing antibodies in humans, eastern province, Saudi Arabia. Emerg Infect Dis. 2013;19(12):2034-6.

171. Corman VM, Albarrak AM, Omrani AS, Albarrak MM, Farah ME, Almasri M, et al. Viral shedding and antibody response in 37 patients with Middle East respiratory syndrome coronavirus infection. Clin Infect Dis. 2016;62(4):477-83.

172. Park SW, Perera RA, Choe PG, Lau EH, Choi SJ, Chun JY, et al. Comparison of serological assays in human Middle East respiratory syndrome (MERS)-coronavirus infection. Euro Surveill. 2015;20(41).

173. Rasmussen SA, Gerber SI, Swerdlow DL. Middle East respiratory syndrome coronavirus: update for clinicians. Clin Infect Dis. 2015;60(11):1686-9.

174. Assiri A, Abedi GR, Saeed AA Bin, Abdalla MA, al-Masry M, Choudhry AJ, et al. Multifacility outbreak of Middle East respiratory syndrome in Taif, Saudi Arabia. Emerg Infect Dis. 2016;22(1):32-40. Available from: http://www.ncbi.nlm.nih.gov/ pmc/articles/PMC4696715/

175. Zumla A, Hui DS, Perlman S. Middle East respiratory syndrome. The Lancet. Lancet Publishing Group. 2015386 995-1007. Available from https://doi.org/10.1016/S01406736(15)60454-8

176. Arabi YM, Balkhy HH, Hayden FG, Bouchama A, Luke T, Baillie JK, et al. Middle East respiratory syndrome. N Engl J Med. 2017 Feb 9 [cited 2021 Apr 17];376(6):584-94. Available from: http://www.nejm.org/doi/10.1056/NEJMsr1408795

177. Memish ZA, Perlman S, Van Kerkhove MD, Zumla A. Middle East respiratory syndrome The Lancet. Lancet Publishing Group 2020395 1063-77. Available from: https:// pubmed.ncbi.nlm.nih.gov/32145185/

178. Momattin H, Al-Ali AY, Al-Tawfiq JA. A systematic review of therapeutic agents for the treatment of the Middle East respiratory syndrome coronavirus (MERS-CoV). Travel Med Infect Dis. 2019 30:9-18. Available from: https:// pubmed.ncbi.nlm.nih.gov/31252170/

179. Park WB, Perera RA, Choe PG, Lau EH, Choi SJ, Chun JY, et al. Kinetics of serologic responses to MERS coronavirus infection in humans, South Korea. Emerg Infect Dis. 2015;21(12):2186-9.

180. Du L, Zhao G, Kou Z, Ma C, Sun S, Poon VKM, et al. Identification of a receptor-binding domain in the S Protein of the novel human coronavirus Middle East respiratory syndrome coronavirus as an essential target for vaccine development. J Virol. 2013;87(21):11963. Available from: http:// www.ncbi.nlm.nih.gov/pmc/articles/PMC3807362/

181. Song F, Fux R, Provacia LB, Volz A, Eickmann M, Becker S, et al. Middle East respiratory syndrome coronavirus spike protein delivered by modified vaccinia virus Ankara efficiently induces virus-neutralizing antibodies. J Virol. 2013;87(21):11950-4.

182. Almazán F, DeDiego ML, Sola I, Zuñiga S, Nieto-Torres JL, Marquez-Jurado S, et al. Engineering a replication-competent, propagation-defective Middle East respiratory syndrome coronavirus as a vaccine candidate. MBio. 2013;4(5):e00650-13 Available from: http://www.ncbi.nlm.nih.gov/pmc/articles/ PMC3774192/.

183. Agnihothram S, Gopal R, Yount Jr. BL, Donaldson EF, Menachery VD, Graham RL, et al. Evaluation of serologic and antigenic relationships between Middle Eastern respiratory syndrome coronavirus and other coronaviruses to develop vaccine platforms for the rapid response to emerging coronaviruses. J Infect Dis. 2014;209(7):995-1006.

184. Riedmann EM. Human vaccines \& immunotherapeutics: news. Hum Vaccin Immunother. 2014;10(6):1427-30 Available from: http://www.ncbi.nlm.nih.gov/pmc/articles/PMC5396245/.
185. Scheiblhofer S, Strobl A, Hoepflinger V, Thalhamer T, Steiner $\mathrm{M}$, Thalhamer J, et al. Skin vaccination via fractional infrared laser ablation - optimization of laser-parameters and adjuvantation. Vaccine. 2017;35(14):1802-9 Available from: http://www.sciencedirect.com/science/article/pii/ S0264410X17300580.

186. Kim E, Okada K, Kenniston T, Raj VS, AlHajri MM, Farag EA, et al. Immunogenicity of an adenoviral-based Middle East respiratory syndrome coronavirus vaccine in $\mathrm{BALB} / \mathrm{c}$ mice. Vaccine. 2014;32(45):5975-82.

187. Kupferschmidt K. INFECTIOUS DISEASE. Camel vaccine offers hope to stop MERS. Science (80). 2015;350(6267):1453.

188. Kupferschmidt K. Camel vaccine offers hope to stop MERS. 20153501453.

189. WHO target product profiles for MERS-CoV vaccines. 2017.

190. Schindewolf C, Menachery VD. Middle east respiratory syndrome vaccine candidates: cautious optimism [Internet]. Viruses MDPI AG 201911 [cited 2021 Apr 17]. Available from: https://pubmed.ncbi.nlm.nih.gov/30658390/

191. Tai W, Wang Y, Fett CA, Zhao G, Li F, Perlman S, et al. Recombinant receptor-binding domains of multiple Middle East respiratory syndrome coronaviruses (MERS-CoVs) induce cross-neutralizing antibodies against divergent human and camel MERS-CoVs and antibody escape mutants. J Virol. 2017;91(1):e01651-16 Available from: http:// www.ncbi.nlm.nih.gov/pmc/articles/PMC5165220/.

192. Chan JF, Chan KH, Kao RY, To KK, Zheng BJ, Li CP, et al. Broad-spectrum antivirals for the emerging Middle East respiratory syndrome coronavirus. J Infect. 2013;67(6):606-16.

193. Hart BJ, Dyall J, Postnikova E, Zhou H, Kindrachuk J, Johnson RF, et al. Interferon-beta and mycophenolic acid are potent inhibitors of Middle East respiratory syndrome coronavirus in cell-based assays. J Gen Virol. 2014;95(Pt 3):571-7.

194. Falzarano D, de Wit E, Rasmussen AL, Feldmann F, Okumura A, Scott DP, et al. Treatment with interferon-alpha2b and ribavirin improves outcome in MERS-CoV-infected rhesus macaques. Nat Med. 2013;19(10):1313-7.

195. Khalid M, Al Rabiah F, Khan B, Al Mobeireek A, Butt TS, Al Mutairy E. Ribavirin and interferon-alpha2b as primary and preventive treatment for Middle East respiratory syndrome coronavirus: a preliminary report of two cases. Antivir Ther. 2015;20(1):87-91.

196. de Wilde AH, Raj VS, Oudshoorn D, Bestebroer TM, van Nieuwkoop S, Limpens RWAL, et al. MERS-coronavirus replication induces severe in vitro cytopathology and is strongly inhibited by cyclosporin A or interferon- $\alpha$ treatment. J Gen Virol. 2013;94(Pt 8):1749-60 Available from: http:// www.ncbi.nlm.nih.gov/pmc/articles/PMC3749523/.

197. Adedeji AO, Sarafianos SG. Future treatment strategies for novel Middle East respiratory syndrome coronavirus infection. Future Med Chem. 2013;5(18):2119-22 Available from: http:// www.ncbi.nlm.nih.gov/pmc/articles/PMC4085789/.

198. Kindrachuk J, Ork B, Hart BJ, Mazur S, Holbrook MR, Frieman MB, et al. Antiviral potential of ERK/MAPK and PI3K/AKT/mTOR signaling modulation for Middle East respiratory syndrome coronavirus infection as identified by temporal kinome analysis. Antimicrob Agents Chemother. 2015;59(2):1088-99.

199. Dyall J, Coleman CM, Hart BJ, Venkataraman T, Holbrook MR, Kindrachuk J, et al. Repurposing of clinically developed drugs for treatment of Middle East respiratory syndrome coronavirus infection. Antimicrob Agents Chemother. 2014;58(8):4885-93.

200. de Wilde AH, Jochmans D, Posthuma CC, ZevenhovenDobbe JC, van Nieuwkoop S, Bestebroer TM, et al. Screening of an FDA-approved compound library identifies four smallmolecule inhibitors of Middle East respiratory syndrome coronavirus replication in cell culture. Antimicrob Agents Chemother. 2014;58(8):4875-84.

201. Xia S, Wang Q, Liu SW, Lu L, Jiang SB. [Development of peptidic MERS-CoV entry inhibitors]. Yao Xue Xue Bao. 2015;50(12):1513-9.

202. Raj VS, Smits SL, Provacia LB, van den Brand JM, Wiersma $\mathrm{L}$, Ouwendijk WJ, et al. Adenosine deaminase acts as a natural antagonist for dipeptidyl peptidase 4-mediated entry of the 
Middle East respiratory syndrome coronavirus. J Virol. 2014;88(3):1834-8.

203. Al-Tawfiq JA, Momattin H, Dib J, Memish ZA. Ribavirin and interferon therapy in patients infected with the Middle East respiratory syndrome coronavirus: an observational study. Int J Infect Dis. 2014;20:42-6.

204. Adedeji AO, Singh K, Kassim A, Coleman CM, Elliott R, Weiss SR, et al. Evaluation of SSYA10-001 as a replication inhibitor of severe acute respiratory syndrome, mouse hepatitis, and Middle East respiratory syndrome coronaviruses. Antimicrob Agents Chemother. 2014/05/21. 2014;58(8):4894-8.

205. Mustafa S, Balkhy H, Gabere MN. Current treatment options and the role of peptides as potential therapeutic components for Middle East Respiratory Syndrome (MERS): A review. J Infect Public Health 2017 Available from: http:// www.sciencedirect.com/science/article/pii/S1876034117302125

206. Kim UJ, Won EJ, Kee SJ, Jung SI, Jang HC. Combination therapy with lopinavir/ritonavir, ribavirin and interferon-alpha for Middle East respiratory syndrome. Antivir Ther. 2016;21(5):455-9.

207. Shalhoub S, Farahat F, Al-Jiffri A, Simhairi R, Shamma O, Siddiqi N, et al. IFN-alpha2a or IFN-beta1a in combination with ribavirin to treat Middle East respiratory syndrome coronavirus pneumonia: a retrospective study. J Antimicrob Chemother. 2015;70(7):2129-32.

208. Chong YP, Song JY, Seo Y Bin, Choi J-P, Shin H-S, Rapid response T. antiviral treatment guidelines for Middle East respiratory syndrome. Infect Chemother. 2015;47(3):212-22. Available from: http://www.ncbi.nlm.nih.gov/pmc/articles/ PMC4607778/

209. Ko JH, Seok H, Cho SY, Ha YE, Baek JY, Kim SH, et al. Challenges of convalescent plasma infusion therapy in Middle East respiratory coronavirus infection: a single centre experience. Antivir Ther. 2018 [cited 2021 Apr 17];23(7):617-22. Available from: https://pubmed.ncbi.nlm.nih.gov/29923831/

210. Arabi YM, Deeb AM, Al-Hameed F, Mandourah Y, Almekhlafi GA, Sindi AA, et al. Macrolides in critically ill patients with Middle East respiratory syndrome. Int J Infect Dis [Internet]. 20191 [cited 2021 Apr 17];81:184-90. Available from: https://pubmed.ncbi.nlm.nih.gov/30690213/

211. Arabi YM, Mandourah Y, Al-Hameed F, Sindi AA, Almekhlafi GA, Hussein MA, et al. Corticosteroid therapy for critically ill patients with middle east respiratory syndrome. Am J Respir Crit Care Med. 201815 [cited 2021 Apr 17];197(6):757-67. Available from: https:// pubmed.ncbi.nlm.nih.gov/29161116/

212. Almutairi AF, Adlan AA, Balkhy HH, Abou Abbas O, Clark AM. "It feels like I'm the dirtiest person in the world.": exploring the experiences of healthcare providers who survived MERS-CoV in Saudi Arabia. J Infect Public Health. 2017 Available from: http://www.sciencedirect.com/science/article/pii/S1876034117301545

213. Tang X-C, Agnihothram SS, Jiao Y, Stanhope J, Graham RL, Peterson EC, et al. Identification of human neutralizing antibodies against MERS-CoV and their role in virus adaptive evolution. Proc Natl Acad Sci U S A. 2014;111(19):E2018-26 Available from: http://www.ncbi.nlm.nih.gov/pmc/articles/ PMC4024880/.

214. Ying T, Du L, Ju TW, Prabakaran P, Lau CC, Lu L, et al. Exceptionally potent neutralization of Middle East respiratory syndrome coronavirus by human monoclonal antibodies. J Virol. 2014;88(14):7796-805.

215. Ohnuma K, Haagmans BL, Hatano R, Raj VS, Mou H, Iwata $\mathrm{S}$, et al. Inhibition of Middle East respiratory syndrome coronavirus infection by anti-CD26 monoclonal antibody. J Virol. 2013;87(24):13892-9.

216. Ying T, Li H, Lu L, Dimitrov DS, Jiang S. Development of human neutralizing monoclonal antibodies for prevention and therapy of MERS-CoV infections. Microbes Infect. 2015;17(2):142-8 Available from: http:// www.sciencedirect.com/science/article/pii/S1286457914003049.

217. Mou H, Raj VS, van Kuppeveld FJM, Rottier PJM, Haagmans BL, Bosch BJ. The receptor binding domain of the new Middle East respiratory syndrome coronavirus maps to a 231-residue region in the spike protein that efficiently elicits neutralizing antibodies. J Virol. 2013;87(16):9379-83 Available from: http:// www.ncbi.nlm.nih.gov/pmc/articles/PMC3754068/.

218. Du L, Zhao G, Yang Y, Qiu H, Wang L, Kou Z, et al. A conformation-dependent neutralizing monoclonal antibody specifically targeting receptor-binding domain in Middle East respiratory syndrome coronavirus spike protein. J Virol. 2014;88(12):7045-53.

219. Chen Y, Lu S, Jia H, Deng Y, Zhou J, Huang B, et al. A novel neutralizing monoclonal antibody targeting the N-terminal domain of the MERS-CoV spike protein. Emerg Microbes Infect . 2017;6(5):e37. Available from: http:// www.ncbi.nlm.nih.gov/pmc/articles/PMC5520482/

220. Jiang L, Wang N, Zuo T, Shi X, Poon KM, Wu Y, et al. Potent neutralization of MERS-CoV by human neutralizing monoclonal antibodies to the viral spike glycoprotein. Sci Transl Med. 2014;6(234):234ra59.

221. Song F, Fux R, Provacia LB, Volz A, Eickmann M, Becker S, et al. Middle East respiratory syndrome coronavirus spike protein delivered by modified vaccinia virus ankara efficiently induces virus-neutralizing antibodies. J Virol. 2013;87(21):11950-4 Available from: http:// www.ncbi.nlm.nih.gov/pmc/articles/PMC3807317/.

222. Du L, Kou Z, Ma C, Tao X, Wang L, Zhao G, et al. A truncated receptor-binding domain of MERS-CoV spike protein potently inhibits MERS-CoV infection and induces strong neutralizing antibody responses: implication for developing therapeutics and vaccines. PLoS One. 2013;8(12):e81587.

223. van Doremalen N, Falzarano D, Ying T, de Wit E, Bushmaker $\mathrm{T}$, Feldmann $\mathrm{F}$, et al. Efficacy of antibody-based therapies against Middle East respiratory syndrome coronavirus (MERS-CoV) in common marmosets. Antivir Res. 2017;143:30-7.

224. Chen Y, Rajashankar KR, Yang Y, Agnihothram SS, Liu C, Lin Y-L, et al. Crystal structure of the receptor-binding domain from newly emerged Middle East respiratory syndrome coronavirus. J Virol. 2013;87(19):10777-83 Available from: http://www.ncbi.nlm.nih.gov/pmc/articles/PMC3807420/.

225. Zhou N, Zhang Y, Zhang JC, Feng L, Bao JK. The receptor binding domain of MERS-CoV: the dawn of vaccine and treatment development. J Formos Med Assoc. 2014;113(3):143-7.

226. Lan J, Yao Y, Deng Y, Chen H, Lu G, Wang W, et al. Recombinant receptor binding domain protein induces partial protective immunity in rhesus macaques against Middle East respiratory syndrome coronavirus challenge. EBioMedicine. 2015;2(10):1438-46 Available from: http:// www.ncbi.nlm.nih.gov/pmc/articles/PMC4634622/.

227. Keil SD, Bowen R, Marschner S. Inactivation of Middle East respiratory syndrome coronavirus (MERS-CoV) in plasma products using a riboflavin-based and ultraviolet light-based photochemical treatment. Transfusion. 2016;56(12):2948-52. https://doi.org/10.1111/trf.13860.

228. Raj VS, Okba NMA, Gutierrez-Alvarez J, Drabek D, van Dieren B, Widagdo W, et al. Chimeric camel/human heavychain antibodies protect against MERS-CoV infection. Sci Adv. 20188 [cited 2021 Apr 17];4(8). Available from: https:// pubmed.ncbi.nlm.nih.gov/30101189/

229. Wang L, Shi W, Chappell JD, Joyce MG, Zhang Y, Kanekiyo $\mathrm{M}$, et al. Importance of neutralizing monoclonal antibodies targeting multiple antigenic sites on the Middle East respiratory syndrome coronavirus spike glycoprotein to avoid neutralization escape. J Virol [Internet]. 2018 Mar 7 [cited 2021 Apr 17];92(10). Available from: https:// pubmed.ncbi.nlm.nih.gov/29514901/

230. Widjaja I, Wang C, van Haperen R, Gutiérrez-Álvarez J, van Dieren B, Okba NMA, et al. Towards a solution to MERS: protective human monoclonal antibodies targeting different domains and functions of the MERS-coronavirus spike glycoprotein. Emerg Microbes Infect [Internet]. 2019 Jan 1 [cited 2021 Apr 17];8(1):516-30. Available from: https:// pubmed.ncbi.nlm.nih.gov/30938227/

231. Gautret P, Benkouiten S, Salaheddine I, Belhouchat K, Drali $\mathrm{T}$, Parola P, et al. Hajj pilgrims knowledge about Middle East respiratory syndrome coronavirus, August to September 2013. Euro Surveill. 2013;18(41):20604. 
232. Khan MU, Shah S, Ahmad A, Fatokun O. Knowledge and attitude of healthcare workers about Middle East respiratory syndrome in multispecialty hospitals of Qassim, Saudi Arabia. BMC Public Health. 2014;14:1281.

233. Alsahafi AJ, Cheng AC. Knowledge, attitudes and behaviours of healthcare workers in the Kingdom of Saudi Arabia to MERS coronavirus and other emerging infectious diseases. Int J Environ Res Public Health [Internet]. 2016;13(12):1214. Available from: http://www.ncbi.nlm.nih.gov/pmc/articles/ PMC5201355/

234. Hoda J. Identification of information types and sources by the public for promoting awareness of Middle East respiratory syndrome coronavirus in Saudi Arabia. Heal Educ Res. 2016;31(1):12-23.

235. Bawazir A, Al-Mazroo E, Jradi H, Ahmed A, Badri M. MERS$\mathrm{CoV}$ infection: mind the public knowledge gap. J Infect Public Health. 2017 Available from: http://www.sciencedirect.com/science/article/pii/S1876034117301351

236. Al-Mohrej OA, Al-Shirian SD, Al-Otaibi SK, Tamim HM, Masuadi EM, Fakhoury HM. Is the Saudi public aware of Middle East respiratory syndrome? J Infect Public Health. 2016;9(3):259 66 Available from: http://www.sciencedirect.com/science/article/ pii/S1876034115001860.

237. Alotaibi MS, Alsubaie AM, Almohaimede KA, Alotaibi TA, Alharbi OA, Aljadoa AF, et al. To what extent are Arab pilgrims to Makkah aware of the middle east respiratory syndrome coronavirus and the precautions against it? J Fam Community Med. 2017;24(2):91-6.

238. Ro JS, Lee JS, Kang SC, Jung HM. Worry experienced during the 2015 Middle East respiratory syndrome (MERS) pandemic in Korea. PLoS One. 2017;12(3):e0173234.

239. Kim JS. Lessons learned from new emerging infectious disease, Middle East respiratory syndrome coronavirus outbreak in Korea. Epidemiol Health. 2015;37:e2015051. Available from: http://www.ncbi.nlm.nih.gov/pmc/articles/PMC4722224/

240. Brown C. Call for infection control to stem MERS. Cmaj. 2014;186(10):E349.

241. Cho SI. Urgent Call for Research on Middle East respiratory syndrome (MERS) in Korea. J Prev Med Public Heal. 2015;48(4):179.

242. Dyer O. South Korea scrambles to contain MERS virus. Bmj. 2015;350:h3095.

243. Ha KM. A lesson learned from the MERS outbreak in South Korea in 2015. J Hosp Infect. 2016;92(3):232-4.

244. Hui DS, Perlman S, Zumla A. Spread of MERS to South Korea and China. Lancet Respir Med. 2015;3(7):509-10.

245. Khan A, Farooqui A, Guan Y, Kelvin DJ. Lessons to learn from MERS-CoV outbreak in South Korea. J Infect Dev Ctries. 2015;9(6):543-6.

246. Lee JK. MERS countermeasures as one of Global Health Security Agenda. J Korean Med Sci. 2015;30(8):997-8.

247. Lim PL. Middle East respiratory syndrome (MERS) in Asia: lessons gleaned from the South Korean outbreak. Trans R Soc Trop Med Hyg. 2015;109(9):541-2.

248. Park HY, Lee EJ, Ryu YW, Kim Y, Kim H, Lee H, et al. Epidemiological investigation of MERS-CoV spread in a single hospital in South Korea, May to June 2015. Euro Surveill. 2015;20(25):1-6.

249. Zumla A, Hui DS. Infection control and MERS-CoV in healthcare workers. Lancet. 2014;383(9932):1869-71.

250. Thys S, Mwape KE, Lefèvre P, Dorny P, Marcotty T, Phiri AM, et al. Why latrines are not used: communities' perceptions and practices regarding latrines in a Taenia solium endemic rural area in Eastern Zambia. PLoS Negl Trop Dis. 2015;9(3):e0003570. Available from: http://www.ncbi.nlm.nih.gov/pmc/articles/ PMC4352092/

251. Conzade R, Grant R, Malik MR, Elkholy A, Elhakim M, Samhouri D, et al. Reported direct and indirect contact with dromedary camels among laboratory-confirmed MERS-CoV cases. Viruses. 2018 Aug 13 [cited 2021 Apr 17];10(8). Available from: https://pubmed.ncbi.nlm.nih.gov/30104551/

252. Alshukairi AN, Khalid I, Ahmed WA, Dada AM, Bayumi DT, Malic LS, et al. Antibody response and disease severity in healthcare worker MERS survivors. Emerg Infect Dis. 2016
Jun 1 [cited 2021 Apr 17];22(6):1113-5. Available from: /pmc/ articles/PMC4880093/

253. Fung IC, Tse ZT, Chan BS, Fu KW. Middle East respiratory syndrome in the Republic of Korea: transparency and communication are key. West Pac Surveill Response J. 2015;6(3):1-2.

254. Fung IC, Fu KW, Ying Y, Schaible B, Hao Y, Chan CH, et al. Chinese social media reaction to the MERS-CoV and avian influenza $\mathrm{A}(\mathrm{H} 7 \mathrm{~N} 9)$ outbreaks. Infect Dis Poverty. 2013;2(1):31.

255. Al-Abaidani IS, Al-Maani AS, Al-Kindi HS, Al-Jardani AK, Abdel-Hady DM, Zayed BE, et al. Overview of preparedness and response for Middle East respiratory syndrome coronavirus (MERS-CoV) in Oman. Int J Infect Dis. 2014;29(Supplement C):309-10. Available from: http://www.sciencedirect.com/ science/article/pii/S1201971214016488

256. Sahin MK, Aker S, Kaynar Tuncel E. Knowledge, attitudes and practices concerning Middle East respiratory syndrome among Umrah and Hajj pilgrims in Samsun, Turkey, 2015. Euro Surveill. 2015;20(38).

257. The Lancet Infectious D. Need for global cooperation in control of MERS-CoV. Lancet Infect Dis. 2013;13(8):639.

258. Walker DH. Value of autopsy emphasized in the case report of a single patient with Middle East respiratory syndrome. Am J Pathol. 2016;186(3):507-10.

259. Ng DL, Al Hosani F, Keating MK, Gerber SI, Jones TL, Metcalfe MG, et al. Clinicopathologic, immunohistochemical, and ultrastructural findings of a fatal case of Middle East respiratory syndrome coronavirus infection in the United Arab Emirates, April 2014. Am J Pathol. 2016;186(3):652-8 Available from: http://www.sciencedirect.com/science/article/pii/ S0002944015006471.

260. Dawson P, Morse S. 20.083 Middle East respiratory syndrome coronavirus (MERS-CoV): a systematic literature review. 2016 53125

261. Balkhy H. MERS CoV: a trigger for healthcare transformation. 20159.

262. Jeong H, Jeong S, Oh J, Woo SH, So BH, Wee JH, et al. Impact of Middle East respiratory syndrome outbreak on the use of emergency medical resources in febrile patients. Clin Exp Emerg Med. 2017;4(2):94-101.

263. Kim CJ, Choi WS, Jung Y, Kiem S, Seol HY, Woo HJ, et al. Surveillance of the Middle East respiratory syndrome (MERS) coronavirus $(\mathrm{CoV})$ infection in healthcare workers after contact with confirmed MERS patients: incidence and risk factors of MERS-CoV seropositivity. Clin Microbiol Infect. 2016;22(10):8806 Available from: http://www.sciencedirect.com/science/article/pii/ S1198743X16302415.

264. El Bushra HE, Al Arbash HA, Mohammed M, Abdalla O, Abdallah MN, Al-Mayahi ZK, et al. Outcome of strict implementation of infection prevention control measures during an outbreak of Middle East respiratory syndrome. Am J Infect Control. 2017;45(5):502-7.

265. Butt TS, Koutlakis-Barron I, AlJumaah S, AlThawadi S, AlMofada S. Infection control and prevention practices implemented to reduce transmission risk of Middle East respiratory syndrome-coronavirus in a tertiary care institution in Saudi Arabia. Am J Infect Control. 2016;44(5):605-11 Available from: http://www.sciencedirect.com/science/article/ pii/S0196655316000419.

266. Tambyah PA, Tay J. The Middle East respiratory syndrome coronavirus (MERS-CoV) and Singapore. Ann Acad Med Singapore. 2013;42(8):376-8.

267. Lee SY, Yang HJ, Kim G, Cheong H-K, Choi BY. Preventive behaviors by the level of perceived infection sensitivity during the Korea outbreak of Middle East Respiratory Syndrome in 2015. Epidemiol Health. 2016;38:e2016051. Available from: http://www.ncbi.nlm.nih.gov/pmc/articles/PMC5309729/

268. Song T, Kang M, Zhang Y, Liang L, Lin H. Elements of successful management of an imported Middle East respiratory syndrome case in Guangdong, China. West Pacific Surveill Response J WPSAR. 2015;6(4):33-4 Available from: http:// www.ncbi.nlm.nih.gov/pmc/articles/PMC4712532/.

269. Rabaan AA, Alhani HM, Bazzi AM, Al-Ahmed SH. Questionnaire-based analysis of infection prevention and control in healthcare facilities in Saudi Arabia in regards to 
Middle East Respiratory Syndrome. J Infect Public Heal. 2017;10(5):548-63.

270. Song Z, Xu Y, Bao L, Zhang L, Yu P, Qu Y, et al. From SARS to MERS, thrusting coronaviruses into the spotlight. Viruses. 2019;11(1):59.

271. Hui DSC, Zumla A. Severe acute respiratory syndrome: historical, epidemiologic, and clinical features. Infectious Disease Clinics of North America. W.B. Saunders 201933 869-89.

272. Chan JF-W, Lau SK-P, Woo PC-Y. The emerging novel Middle East respiratory syndrome coronavirus: the "knowns" and "unknowns." J Formos Med Assoc. 2013;112(7):372-81. Available from: http://www.sciencedirect.com/science/article/pii/ S0929664613001770

273. Kim JS, Choi JS. Factors influencing emergency nurses' burnout during an outbreak of Middle East respiratory syndrome coronavirus in Korea. Asian Nurs Res (Korean Soc Nurs Sci). 2016;10(4):295-9.

274. Song JY, Cheong HJ, Choi MJ, Jeon JH, Kang SH, Jeong EJ, et al. Viral shedding and environmental cleaning in Middle East respiratory syndrome coronavirus infection. Infect Chemother. 2015;47(4):252-5.

275. Yang L, Tian D, Liu W. Strategies for vaccine development of COVID-19. Shengwu Gongcheng Xuebao/Chinese Journal of Biotechnology. Chinese Academy of Sciences; 202039 593604.

276. Alraddadi BM, Qushmaq I, Al-Hameed FM, Mandourah Y, Almekhlafi GA, Jose J, et al. Noninvasive ventilation in critically ill patients with the Middle East respiratory syndrome. Influenza Other Respi Viruses. 20191 [cited 2021 Apr 17];13(4):382-90. Available from: https:// pubmed.ncbi.nlm.nih.gov/30884185/

277. Lee SM, Kang WS, Cho AR, Kim T, Park JK. Psychological impact of the 2015 MERS outbreak on hospital workers and quarantined hemodialysis patients. Compr Psychiatry. 2018 Nov 1 [cited 2021 Apr 17];87:123-7. Available from: /pmc/ articles/PMC7094631/

278. Kim KH, Tandi TE, Choi JW, Moon JM, Kim MS. Middle East respiratory syndrome coronavirus (MERS-CoV) outbreak in South Korea, 2015: epidemiology, characteristics and public health implications. J Hosp Infect. 20171 [cited 2021 Apr 17];95(2):207-13. Available from: https:// pubmed.ncbi.nlm.nih.gov/28153558/

279. Oh MD, Park WB, Park SW, Choe PG, Bang JH, Song KH, et al. Middle east respiratory syndrome: what we learned from the 2015 outbreak in the republic of Korea Korean Journal of Internal Medicine. Korean Association of Internal Medicine 201833 [cited 2021 Apr 17]. p. 233-46. Available from: https:// pubmed.ncbi.nlm.nih.gov/29506344/

280. Hui DS, Azhar EI, Kim YJ, Memish ZA, Oh M don, Zumla A. Middle East respiratory syndrome coronavirus: risk factors and determinants of primary, household, and nosocomial transmission. The Lancet Infectious Diseases. Lancet Publishing Group 201818 [cited 2021 Apr 17] e217-27. Available from https:// doi.org/10.1016/S1473-3099(18)30127-0

281. Ahmed AE. The predictors of 3- and 30-day mortality in 660 MERS-CoV patients. BMC Infect Dis. 201711 [cited 2021 Apr 17];17(1):615. Available from: http:// bmcinfectdis.biomedcentral.com/articles/10.1186/s12879-0172712-2

282. Park JE, Jung S, Kim A. MERS transmission and risk factors: a systematic review. BMC Public Health [Internet]. 20182 [cited 2021 Apr 17];18(1):574. Available from: https:// bmcpublichealth.biomedcentral.com/articles/10.1186/s12889018-5484-8

283. Rahman A, Sarkar A. Risk factors for fatal Middle East respiratory syndrome coronavirus infections in Saudi Arabia: Analysis of the WHO Line list, 2013-2018. Am J Public Health. 2019 [cited 2021 17];109(9):1288-93. Available from: https://pubmed.ncbi.nlm.nih.gov/31318592/

284. Sha J, Li Y, Chen X, Hu Y, Ren Y, Geng X, et al. Fatality risks for nosocomial outbreaks of Middle East respiratory syndrome coronavirus in the Middle East and South Korea. Arch Virol [Internet]. 2017 Jan 1 [cited 2021 Apr 17];162(1):33-44. Available from: https://pubmed.ncbi.nlm.nih.gov/27664026/

285. Seys LJM, Widagdo W, Verhamme FM, KleinJan A, Janssens W, Joos GF, et al. DPP4, the Middle East respiratory syndrome coronavirus receptor, is upregulated in lungs of smokers and chronic obstructive pulmonary disease patients. Clin Infect Dis. 2018 Jan 1 [cited 2021 Apr 17];66(1):45-53. Available from: https://pubmed.ncbi.nlm.nih.gov/29020176/

286. Batawi S, Tarazan N, Al-Raddadi R, Al Qasim E, Sindi A, Al Johni S, et al. Quality of life reported by survivors after hospitalization for Middle East respiratory syndrome (MERS). Health Qual Life Outcomes. 2019 Jun 11 [cited 2021 Apr 17];17(1). Available from: https://pubmed.ncbi.nlm.nih.gov/31186042/

287. Ngai JC, Ko FW, Ng SS, To KW, Tong M, Hui DS. The longterm impact of severe acute respiratory syndrome on pulmonary function, exercise capacity and health status. Respirology. 2010 Apr [cited 2021 Apr 17];15(3):543-50. Available from: https://pubmed.ncbi.nlm.nih.gov/20337995/

288. Das KM, Lee EY, Singh R, Enani MA, Al Dossari K, Van Gorkom K, et al. Follow-up chest radiographic findings in patients with MERS-CoV after recovery. Indian J Radiol Imaging. 2017 Jul 1 [cited 2021 Apr 17];27(3):342-9. Available from: /pmc/articles/PMC5644332/

289. Jha N, Jeyaraman M, Rachamalla M, Ojha S, Dua K, Chellappan D, et al. Current understanding of novel coronavirus: molecular pathogenesis, diagnosis, and treatment approaches. Immuno. 2021 Mar 26 [cited 2021 Apr 17];1(1):3066. Available from: https://www.mdpi.com/2673-5601/1/1/4

290. Abdelrahman Z, Li M, Wang X. Comparative review of SARS-CoV-2, SARS-CoV, MERS-CoV, and Influenza A respiratory viruses. Frontiers in Immunology. Frontiers Media S.A.; 202011 [cited 2021 Apr 17]. Available from: /pmc/ articles/PMC7516028/

291. Roychoudhury S, Das A, Jha NK, Kesari KK, Roychoudhury $\mathrm{S}$, Jha SK, et al. Viral pathogenesis of SARS-CoV-2 infection and male reproductive health: Covid-19 and male fertility 11 Open Biology. Royal Society Publishing 2021 [cited Apr 17] 200347. Available from: https://research.aalto.fi/en/publications/viral-pathogenesis-of-sars-cov-2-infection-and-malereproductive-

292. Jha NK, Ojha S, Jha SK, Dureja H, Singh SK, Shukla SD, et al. Evidence of Coronavirus $(\mathrm{CoV})$ pathogenesis and emerging pathogen SARS-CoV-2 in the nervous system: a review on neurological impairments and manifestations. Journal of Molecular Neuroscience. Humana Press Inc.; 2021 [cited 2021 Apr 17]. Available from: https://covid19.elsevierpure.com/pl/ publications/evidence-of-coronavirus-cov-pathogenesis-andemerging-pathogen-sa

Publisher's Note Springer Nature remains neutral with regard to jurisdictional claims in published maps and institutional affiliations. 